\title{
Addition Probiotics on Captive Fish Nutrition the benefits, water quality and productive performance: a review
}

The processes of technological innovation influence the great advances in the world agribusiness sector. These progresses are the result of scientific and technological studies. In this context, fish farming appears as an alternative to diversify agricultural production, being the most responsible system in the world for food security. In addition, the practice of fish farming is a potential strategy for environmental conservation since it contributes to capture fisheries reduction. However, the traditional management commonly adopted in fish farming results in innumerable environmental consequences such as: pollution of water bodies and introduction of exotic species, generation of effluents, emergence of diseases in man and animals. Probiotics as a dietary supplement for captive-bred fish appear as an alternative resource, aiming to improve the zootenic and sanitary performance of fish, healthy conditions and increase production with efficiency. It should be noted that diets are related to ethological aspects, structural integrity, sanity, physiology, reproduction, growth, and sanitary or environmental conditions. The present study aimed to revise assessments on the use of functional food additives in captive-bred fish diet and the results obtained by their administration. A qualitative approach was used with a descriptive and documentary method. The data analysed here contribute to further studies and to glimpse the potentials of nutrition of captive fish, considerating that negative impacts to the environment, production and quality of fish can be mitigated.

Keywords: Probiotics; Nutrition; Fish farming; Fish sanity; Water quality.

\section{Adição probióticos na nutrição de peixes em cativeiro, os benefícios, qualidade da água desempenho produtivo: uma revisão}

\begin{abstract}
Os processos de inovação tecnológica influenciam os grandes avanços no setor mundial do agronegócio. Esses avanços são resultado de estudos científicos e tecnológicos. Nesse contexto, a piscicultura aparece como uma alternativa para diversificar a produção agrícola, sendo o sistema mais responsável do mundo pela segurança alimentar. Além disso, a prática de piscicultura é uma estratégia potencial para a conservação ambiental, pois contribui para capturar a redução da pesca. No entanto, o manejo tradicional comumente adotado na piscicultura resulta em inúmeras conseqüências ambientais, tais como: poluição de corpos d'água e introdução de espécies exóticas, geração de efluentes, surgimento de doenças no homem e nos animais. Os probióticos como complemento alimentar de peixes criados em cativeiro aparecem como um recurso alternativo, com o objetivo de melhorar o desempenho zootênico e sanitário dos peixes, condições saudáveis e aumentar a produção com eficiência. Note-se que as dietas estão relacionadas a aspectos etológicos, integridade estrutural, sanidade, fisiologia, reprodução, crescimento e condições sanitárias ou ambientais. O presente estudo teve como objetivo revisar avaliações sobre o uso de aditivos alimentares funcionais na dieta de peixes em cativeiro e os resultados obtidos por sua administração. Utilizou-se abordagem qualitativa, com método descritivo e documental. Os dados aqui analisados contribuem para novos estudos e vislumbram as potencialidades da nutrição de peixes em cativeiro, considerando que impactos negativos ao meio ambiente, produção e qualidade dos peixes podem ser mitigados.
\end{abstract}

Palavras-chave: Probióticos; Nutrição; Piscicultura; Sanidade de peixes; Qualidade da água.

Topic: Desenvolvimento, Sustentabilidade e Meio Ambiente

Reviewed anonymously in the process of blind peer
Received: 04/02/2021

Approved: 25/02/2021
Lucimar Rodrigues Vieira (iD)

Instituto Federal de Mato Grosso, Brasil http://lattes.cnpq.br/3404632513616619 http://orcid.org/0000-0003-1583-9709

lucimar.curvo@cba.ifmt.edu.br

Milena Wolff Ferreira (iD)

Universidade Católica Dom Bosco, Brasil http://lattes.cnpq.br/5818612531114338 http://orcid.org/0000-0001-9763-2239 milenawolff@ucdb.br

Guilherme Ribeiro Capibaribe Barbosa (iD Universidade Católica Dom Bosco, Brasil http://lattes.cnpq.br/2804417103403706 http://orcid.org/0000-0003-2252-5054 guilhermeribeiro15900@gmail.com

\author{
Franciele Itati Kreutz (iD) \\ Universidade Católica Dom Bosco, Brasil \\ http://lattes.cnpq.br/1586157479065244 \\ http://orcid.org/0000-0001-6009-5185 \\ kreutz.rezende@gmail.com \\ Celso Soares Costa (iD \\ Instituto Federal de Mato Grosso do Sul, Brasil \\ http://lattes.cnpq.br/7923376910013517 \\ http://orcid.org/0000-0001-7040-7058 \\ celso.costa@ifms.edu.br \\ Ulisses Simon Silveira \\ Instituto Federal de Mato Grosso do Sul, Brasil \\ http://lattes.cnpq.br/8930766862673933 \\ http://orcid.org/0000-0001-9416-0571 \\ ulissessimon@hotmail.com
}

Gisele Braziliano de Andrade (ID)

Universidade Católica Dom Bosco, Brasil http://lattes.cnpq.br/8195782106387584 http://orcid.org/0000-0001-6289-9945 gisele@ucdb.br
Referencing this:

VIEIRA, L. R.; FERREIRA, M. W.; BARBOSA, G. R. C.; KREUTZ, F. I.; COSTA, C. S.; SILVEIRA, U. S.; ANDRADE, G. B.. Addition Probiotics on Captive Fish Nutrition the benefits, water quality and productive performance: a review. Revista lbero Americana de Ciências Ambientais, v.12, n.2, p.457-481, 2021. DOI: http://doi.org/10.6008/CBPC2179-6858.2021.002.0040 


\section{INTRODUCTION}

From the beginnings of human being and domestication of plants and animals, agriculture has been based on the technology of land use and labor, that is, in the exploitation of natural resources (NAVARRO, 2017; BARROS, 2018). The same assumption can be observed for aquaculture activity, which consists of the production and cultivation of organisms that have at least one stage of their life cycle in an aquatic environment with commercial and economic values (SCHULTER et al., 2017).

In the current context, the arrival of new companies, fast professionalization and technological intensification increased brazilian aquaculture production to 123\%, from 257 thousand tons of fish in 2005 to 574 thousand in 2015 (PEDROZA FILHO et al., 2016; SILVA et al., 2018). The production scenarios have indicated progressive increases, and according to data from the statistical yearbook of the Brazilian Association of Farming Fishes there was an 8.44\% increase from years 2015, totaling in 2019, 758 thousand tons.

Fish farming is a form of aquaculture that consists of the breeding of fish in artificial environments" (LUCA et al., 2017). This activity can serve the leisure, generating added economic value. In this aspect it provides an efficient way to intensify the conservation of the natural resources, through management models more adapted to the reality of each region (LUCA et al., 2017; ZANIBONI FILHO et al., 2018).

In the context of global fish farming, according to the Food and Agriculture Organization of the United Nations (FAO, 2018) 59.6 million people were involved in the primary sector of capture fisheries (professional fishing) and aquaculture in 2016. Of the people involved in the activities, 85\% were in Asia, $10 \%$ in Africa and 4\% in Latin America and the Caribbean (FAO, 2018). According to the FAO (2018), per capita fish consumption in food ranged from $9.0 \mathrm{~kg} /$ year in 1961 to $20.2 \mathrm{~kg} /$ year in 2015, at an average growth rate of $1.5 \%$ per year. In this sense, with a view to captive fish production in Brazil, a historical increase in production is observed (TORRES et al., 2017), such historical relation has intensified with the creation of public policies of governmental incentives (SILVA, 2005; ROCHA et al., 2013). This growth has made the Brazilian fish industry gain more importance in the world economy, due to the increase in the demands of foreign trade (BANDEIRA et al., 2017). Fish production for human consumption has become an important market in the gastronomy sector, since the product has great nutritional value (LUCA et al., 2017), appreciable flavor (BARBOSA et al., 2006) and which highlights the needs of consumers and accessed to quality proteins (BANDEIRA et al., 2017).

Based on the premise that captive fish breeding can be improved in aspects related to productive performance, improvement of water quality, modulation intestinal morphological and microbiota in fish farms, aim reduction of pathologies. Vieira et al. (2016) reports that in order to evolve in the quantitative and qualitative scenario of the production of fish, the challenge is to incorporate technologies that will change the traditional connotation of production, how the use of probiotics. These same authors believe that with the introduction and use of functional foods, it is possible to improve animal (SAFRA et al., 2018) and human health conditions (BARRETO, 2018) and also increase productivity (VIEIRA et al., 2016).

In view of these findings, it is questionable to analyze whether the addition of functional foods in the 
diet of captive-bred fish contributes to the increase in quantity and quality of production and to influence environmental conditions? It is therefore agreed that it is important to evaluate or increase production through fish farming, but the capacity for environmental resilience, because productive activity can affect the effects (ZANIBONI FILHO et al., 2018)

It is observed that the use of additives, incorporated into the diet of cultured fish, has been evaluated as a promising resource, which contributes significantly to fish diet management. It is also worth noting that tanks cultivation has sanitary, environmental and nutritional peculiarities, which can be improved by using supplementation, contributing to sustainability and health in general (NWACHI, 2013).

Numerous researches have sought to evaluate alternative technological resources to replace the use of harmful inputs in all chains (DEROME et al., 2020; AMENYOGBE et al., 2020), and have given great importance to the use of food additives, as a way of supplement the foods used in fish farming (BISWAS et al., 2019; DEROME et al., 2020), still with the purpose of reducing economic and health problems and providing safe and quality products to the consumer (AMENYOGBE et al ., 2020; DEROME et al., 2020).

Modern techniques have used the addition of several products and substances of living organisms in the diet of animals (Prebiotics and Probiotics), believing that this complementation will bring benefits to these living organisms and to the environment (FUIIMOTO et al., 2015). In the case of captive fish farming, research evaluates the use of probiotic supplementation in the diet (JATOBÁ et al., 2018).

Mukherjee et al. (2016) mentioned that probiotics include Gram-positive, Gramnegative bacteria, and many other organisms such as yeasts, bacteriophage, and single-celled algae. The main benefits of administering live additives (bacteria and yeasts, mainly) in the fish diet are: higher growth, feed conversion rate and protein efficiency, digestibility, carcass yield in terms of chemical composition, response immunological effects on pathogens and metabolic efficiency in the prevention and improvement of diseases, water quality and morphophysiological alterations at molecular and systemic levels (FERREIRA et al., 2014; HUSSAN et al., 2016; ALLAMEH et al., 2017; WANKA et al., 2018; BRITO et al., 2019).

In this perspective, we propose to evaluate the reports of probiotics addition in captive-bred fish feeding, with the aim of identifying the benefits, productive performance and water quality conditions of the fish culture environment. In addition, this study seeks to evaluate the possible environmental implications resulting from the practice of fish farming activity. Mukherjee et al. (2016); Yang et al. (2019); identified several benefits of adding food supplements to live and non-living fish, including: increased performance, increased immunological parameters and recolonization of the intestinal microbiota.

In two reviews, Zorriehzahra et al. (2016); Mamun et al. (2019) tabulated results of research involving probiotics in host fish, and showed studies on 21 different fish species, in 34 articles published in international journals from 1990 to 2012, evaluating 15 genera of bacteria (Aeromonas, Enterobacter, Shewanella, Bacillus, Brevibacillus, Clostidium, Carpobacteria, Enterococus, Kocura, Vagococcus, Rhodococus, Lactobacillus, Leuconostoc, Pediococcus and their potential probiotics and important results were obtained.

Aiming at proposing the logical triggering of the ideas addressed, this work was elaborated according to the following structure: in the first section the introduction, with the contextualization, justification, the 
objectives and the presentation of the topics; in the second one, we have the methodological approaches addressed for the construction of the bibliographic review; the third topic highlights the biological and sanitary aspects inherent to fish farming inphasizing the importance of water quality, nutritional aspects, the use of probiotics, and productive additives, as well as environmental sanitation; the fourth topic presents the final considerations followed by the bibliographical references.

\section{METHODOLOGY}

This research is authorized and registered with the Ethics Committee on the Use of Animals (CEUA) of Universidade Católica Dom Bosco under protocol no 015/2019. The precepts of Law No. 11,794, of October 2008 , of Decree no. 6,899 , of July 15, 2009, and the rules issued by the National Council for Animal Experimentation Control (CONCEA) (BRASIL, 2019) were strictly obeyed. The photos of animal organs and tissues are part of the collection of histological slides Laboratory of Pathological Anatomy of the Catholic University Don Bosco (UCDB).

This research has a narrative review of specialized literature, based on the mention of the main researches and or most important sources, on methodological assumptions according to Gil (2008); Flick (2013); Prodanov (2013), consisting of information correlated to Fish farming, Zootechnology, Limnology, Probiotic Use, Water Quality, Productive Performance and Morphological Alterations of captive-bred fish. It was defined as limitation of choice, work and studies developed on the use of probiotics in fish farming, being a criterion of choice publications from 1980 of 2020.

Scientific materials through the worldwide computer network (internet) reliable data and search sites, predominantly, such as: Google Scholar, Scientific Electronic Library Online (SciElo), Scopus, SciDirect, Cochrane Library and Newspaper. It was also consulted, Elsevier, Francis and Taylor, Hindawi, Wiley online Library, NCBI (National Center for Biotechnology Information), Frontiers, Group Eumed (Univerdidad de Málaga), Springer Nature and of CAPES/MEC of Brazil, in the mains journals: Experimental Biology, Acta Histochemica, Journal of Histology, Fishes, Freshwater Biology, Veterinary Parasitology, Aquaculture, Journal of Animal Science, Renewable Agriculture and Food Systems, Reviews in Aquaculture, Aquaculture Nutrion, Journal of Applied Bacteriology, Food Research International, Freshwater Biology, Ecology of Freshwater Fish, International Journal of Fisheries and Aquaculture e Journal of Fish Biology, The Anatomical Record, PubMed (National Library of Medicine), and others included a total of 173 publications used, mostly in English language and in international journals.

This study was carried out from January 2019 to July 2020. The following terms were used: probiotics, symbiotics, probiotic fish, water quality, water quality and probiotics, fish performance, morphometry, probiotic morphophysiological changes.

\section{THEORETICAL DISCUSSION}

Sanitary and biological aspects inherent to high efficiency in the creation of fish 


\section{Fish farming: association between environmental and nutritional management}

According to Santos et al. (2012), fishing activity is very old in Brazil and since the earliest days of prehistory, human groups have already used fish as a food resource. More recently, already in the first decades of the twentieth century, the fishing activity that was previously related to the small production began to be produced in large scale (DIEGUES, 2006; CRUZ et al., 2018).

The production of fish in captivity has been increasing to meet the human needs of animal protein intake, being characterized as a very promising agricultural activity, according to Bandeira et al. (2017); Akanmu (2018). However, it is not conceivable to increase production without evaluating other variables such as: social responsibility, principles of environmental conservation, sanitation, quality of production and effective means of commercialization and accessed to the population (MATIAS, 2016).

According to Itauassú et al. (2018), the economic attractiveness of fish farming has encouraged the opening of new production frontiers, and this, in turn, has been causing pressure on local water bodies, since it is from these that the main input of fish farming water is captured to enable production. Therefore, like any other economic activity, this requires basic planning and strategies to produce good results from the economic, social and environmental point of view (MARQUES et al., 2016; ZANIBONI FILHO et al., 2018).

In Brazil, many new scientific studies have developed new technologies to improve fish growth and development (ROCHA et al., 2013), mainly in relation to fish feeding management (CYRINO et al., 2010). These authors grouped together several technological advances that are being incorporated into the productive chain of captive-bred fish, such as: productive management, genetic improvement, environmental aspects, and addition of nutrients and additives in food.

Studies of the nutritional aspects of aquatic animals started in the decade of 1970 (VILA et al., 2010; ALLAMEH et al., 2017), with great emphasis on the importance of captive fish nutrition, considering that this phase of cultivation is essential for success of the production, either from the environmental point of view, or from the financial return, and also from fish quality (SOUTO et al., 2016). These authors argue that the feeding of fish in captivity is directly associated with the species, since the types of food are related to the adaptive amplitude and the diversity of the diet of each one (SOUTO et al., 2016). Thus, diets are related to ethological aspects, structural integrity, sanity, physiology, reproduction, growth, and sanitary or environmental conditions (ALLAMEH et al., 2017).

Therefore, it is clear that nutritional needs for captive fish farming, mainly confined to excavated landfills, must be met by the provision of commercial feed, with or without additives, which meet their requirements to improve productive performance and low costs (ALLAMEH et al., 2017), and with higher environmental sustainability (CARDOSO et al., 2016).

In this aspect, it is corroborated by Cyrino et al. (2010) who believe that in order to achieve efficient production in fish farming, it is essential to focus on management, water quality, nutrition and food. If these assumptions are not observed, fish growth will be impaired, resulting in losses to the producer (LEIRA et al., 2017). In other words, being more specific, understand that production should be conceived as a more 
sustainable perception, using risks and ecological balance, reducing the negative impacts of fish farming at all scales (AKANMU, 2018).

In artificial aquatic environments, many stressors appear, which can compromise the health and wellbeing of fish, due to the presence of pathologies, and consequent reduction in production (FERNANDES et al., 2017). According to these authors, the control of environmental factors to increase environmental quality has been carried out through the use of antibiotics, which can be harmful to man, other beings and the ecosystem.

\section{Productive additives and their benefits in breeding fish in captivity}

Important productive additives used in fish farming and in various diets of captive animals are probiotics and prebiotics. With the demand for growing food, several challenges for society emerge, especially in terms of efficiency in food production that will improve health and increase food productivity (RODILES et al., 2018). For these same authors, the use of functional foods such as probiotics, prebiotics and symbiotics appears as an alternative form for these purposes, and has aroused great interest in the scientific community, being tested in controlled experiments to evaluate possible benefits to fish production, health condition and socio-environmental health.

The term probiotic has its latin etymological origin "pro bios", which designates "in favor of life." Originally used for the first time by Lilly and Stiwell, in the 1965 decade (GASTESOUPE, 1999). According to this same author "is defined as being a set of organisms and substances that contribute to the balance of microorganisms in the gastrointestinal tract".

Fuller (1989); Thassi et al. (2016); Yang et al. (2019) described probiotics as food supplements composed of living microorganisms that benefit host health by balancing the intestinal microbiota. For Mello et al. (2013), probiotics are a complement that microorganisms not only cause benefits to the host, but also interfere directly in the body's functioning, ensuring even greater nutritional values, besides increasing defensive responses against pathogens and improving water quality. Chandrakala et al. (2017), mentioned that probiotics help increase the decomposition of undesirable organic substances, improve the ecological environment, as they minimize the effects of toxics as $\mathrm{NH}_{3}, \mathrm{NH}_{4}^{+} \mathrm{NO}_{2}^{-}, \mathrm{NO}_{3}^{-}$and methane.

There are several types of organisms listed with probiotic action. Teixeira (2001); Valentin et al. (2017) classified as follow: Aerobes (Bacillus cereus, B.coagulans and B. subtilis); Anaerobes (Clostridium butrirycum); producers of lactic acid (Bifidobacterium thermofilum, B. pseudolegum, Lactobacillus acidophilum, L. salivarius, Enterococcus faecalis, E. faecium); (Streptococcus, Lactobacillus, Bacillus, and Bifidobacterium $s p$ ) and yeasts.

Other authors cited the various organisms that are also used as probiotics in fish farming. Chandrakala et al. (2017) listed the following microorganisms: Lactobacillus, Bifidobacterium, Pediococcus. Lake Streptococcus and Carnobacterium spp., Bacillus, Flavobacterium, cytophage, Pseudomonas, Alteromonas, Aeromonas, Enterococcus, Nitrosomonas, Nitrobacter and Vibrio spp., Saccharomyces and Debaryomyc. 
Coppola et al. (2004) also listed other species with potential for uses such as probiotics: Lactobacillus (L. acidophilus, L. amylovorus, L. casei, L. crispatus, L. delbrueckiisubsp. Bulgaricus, L. gallinarum, L. gasser, L. johnssonii, L. paracasei, L. plantarum, L. reuteri, L. rhamnosus); Bifidobacterium (B. adolescentes, B. animalis, B. bifidum, B. breve, B. infantis, B. lactis, B. longum); Enterococcus (E. faecalis, E. faecium), Lactococcus lactis, Leuconstoc mesenteroides, Pediococcusacidilactici, Sporolactobacillusinulinus, Streptococcusthermophilus, Bacillus cereus var. toyoi, Escherichia coli cepa nissle, Propionibacterium freudenreichii and Saccharomyces cerevisia.

Aquatic animals, especially fishes, have water as their natural habitat, enabling them to come in contact with a number of pathogenic organisms, which can cause disease, change the internal and external environmental conditions of cultivated animals and cause losses in production (VIEIRA et al., 2016).

Thaissi et al. (2016); Brito et al. (2019) pointed out that the use of probiotic strains associated with commercial food destined to captive fish feed effectively acts on these animals and improves productive performance, food efficiency, immune system growth, and also promotes a control of the intestinal microbiota infection of the host, reducing the rate of disease, functioning similarly to a barrier for the entry of pathogens.

There are many mechanisms of action of probiotics in the host organism, the most accepted one was elaborated from the theoretical concept of community ecology, where species of the same community occupying similar ecological niches establish an inharmonious interspecific relationship of competition in the environment, disputing resources in the habitat that they are inserted, created in 1934 by the Russian biologist Georgy Gause (1910-1986) (FERREIRA et al., 2018). According to the Gause Law, two or more species with similar ecological niches can not coexist due to the evolutionary pressures of competition. In one way, one of the organisms will override the other, and may cause morphological and ethological changes and even death or extinction of the other species. The limiting factors for these communities are resources such as water, food, abiotic conditions, and mechanisms of defense and impairment of reproductive processes and/or toxicity. In the narrower sense, probiotics find or transform local conditions in environments more favorable to their multiplication and feeding.

\section{Water quality and its influence on the performance of cultured fish}

The intensification of production practices in crops with high densities (storage) require adequate strategies and technological resources, in view of the conditions of the use of inappropriate inputs, excessive discharge of organic and inorganic materials, hinder environmental resilience, necessary adaptation (OPIYO et al., 2019; DEROME et al., 2020) and ecosystem restructuring (NOBILE et al., 2019; DEROME et al., 2020).

Water is one of the most important molecules for the existence of any form of life (BACCl and PATACA, 2008). Kubitza (2011); Cardoso et al. (2016) understand that water is a very important environmental factor for fish, since all their vital functions take place in it (MAGALHÃES et al., 2014). When using the terminology "water quality", it is not limited to its purity or potability and direct consumption, but the physical, chemical and biological characteristics suitable for a particular use in an activity or purpose 
(ANA, 2005).

Magalhães et al. (2014) remark that the non-observance of the nurseries water quality causes the occurrence of diseases and, still, affects the quantity and quality of the food in these properties. In the productive aspect, there is no mention of total potability for direct consumption. The conditions of the nurseries must have adequate conditions that will guarantee the sanity of the fish also do not endanger human populations and the environment (SIPAÚBA-TAVARES et al., 2010). In the same sense, the authors argue that physical, chemical and biological parameters should be monitored to prevent these risks to human, animal and environmental health and not to hinder production.

Fishes require ideal conditions for survival, development and therefore a profitable production for the producer, demanding constant monitoring of the parameters that indicate the water quality of nurseries (FIGUEIRÓ et al., 2018).

In the same sense, Leira et al. (2017) commented that when nurseries do not have the ideal water quality for cultivation, breeding, health, and fish quality, they can be compromised, causing damage to the crop. There is a number of problems that may arise due to inadequate water quality, such as: eutrophication, animal stress, fish low immunity, colonization of harmful microorganisms (pathogenic), intoxication, pollution of water resources (LEIRA et al., 2017).

It is justified the concern and needs of water quality maintenance in fish farming nurseries, since when they are raised in confinement they suffer from the various physical, chemical and biological environmental stressors (CAVALHEIROS et al., 2014). These authors mentioned other stressors of captivebred fish that arise through the confinement, such as handling practices, transportation, treatments and high storage densities.

It should be noted that the mechanisms that fish have to respond to or adapt to stressors are crucial to maintain their homeostasis, being the main cause of the emergence of pathologies (SILVEIRA et al., 2009; PEREIRA et al., 2016). For these same authors, stress becomes a factor that interferes with growth and reproduction, when it becomes the physiological response to the stimulus, that is, it goes against redirecting and channeling the energy demand to other activities aimed at homeostatic rebalancing, using their reserves for respiration, locomotion, hydromineral balance and tissue repair.

Thus, the sanitary conditions of the nurseries, that is, the water quality becomes a stress factor for the fish, since the ideal parameters for the crop should be close to the ideal, requiring constant monitoring. In artificial environment fishes are exposed to several stressors caused by seasonal variations, which are detrimental to fish (JAHANGIRI et al., 2018).

When fishes are exposed to harmful agents to their development, the consequences can result in instantaneous death, population reduction or even compromise the integrity of the organs and their functions, as they promote morphological and biochemical changes (histological, anatomical and physiological) (MARCON et al., 2015). It reaches all levels of animal organization (molecular to organic) inhibiting their basic vital functions (LIEBEL et al., 2013).

Thus, it becomes timely to reflect on the sanity of fish bred in captivity, since these directly interfere 
with the production and the issue of the health of the potential consumer. Araújo et al. (2009); Mohammadi et al. (2016) outlined sanity as being the "anatomical-physiological integrity of all organisms, justifying the absence of diseases that may come to them".

According to Garutti (2003); Wanja et al. (2020) the exogenous materials modified the limnological parameters and consequently can favor the multiplication of pathogens in that environment, which cause pollution when in contact with the bodies of water. These authors believe in the possibility of an ecological fish farm, in which the enterprise is planned, allowing basic management practices, making it possible to maximize production and development.

The control of undesirable organisms in the water of fishponds is usually done through antibiotics, which is not recommended because it generates bacterial resistance, causing health risks (FERNANDES et al., 2017). The use of probiotics in aquaculture has been widely used to minimize the impacts caused by water (BAHNASAWY et al., 2020).

Mohapatra et al. (2013) reported that species of gram-positive bacteria of the genus Bacillus enhance the immune system of the fish and also promote improvements in the water quality of the breeders, converting organic substances into bacterial biomass, demand for dissolved oxygen. Algicidal effects, reducing the toxicity of nitrogen compounds by the recolonization of nitrifying and denitrifying strains.

Fishes are directly exposed to all the biotic and abiotic factors of the nurseries that directly interfere in their productive performance, necessitating a complement in the nutrition that will contribute to the control of these colonizations (VIEIRA et al., 2016).

Recent studies have evaluated the influence of abiotic and biotic factors in fish reared in captivity, such as pH (SYLVAIN et al., 2016), temperature, salinity (SCHMIDT et al., 2015) microbiota (HUYBEN et al., 2018) in terms of colonization, development, metabolic and physiological (SÁENZ et al., 2019). In light of these recent advances, these same authors added that the conditions of cultivation and their pathogenic or undesirable colonization can lead to the imbalance of the environment, becoming a threat to fish farming, to the environment and for man himself. It is possible, through functional foods like probiotics, to inhibit, reduce and change nursery conditions, promoting resistance, protection and activation of metabolic systems in animals and the ecosystem (DEROME et al., 2020).

\section{Sanitary conditions and productive performance}

The sanitary conditions of nurseries and fish feed are of extreme importance in order to guarantee efficient production, high performance, and also guarantee the fish and consumer health (CARDOSO FILHO et al., 2011). At this point, environmental conditions, encompassing all physical, chemical and biological parameters, allow changes in the colonization of organisms, which may or may not be beneficial and modify the vital functions for fish survival in the nursery (BRITO et al., 2019). The type of feed is a determinant of the water quality and its composition, directly influencing the seasonality of the physical, chemical and biotic parameters (FERREIRA et al., 2018).

Protein-rich, nucleic acid and aminoácid desrations, when passing through catabolic processes, 
generate toxic residues such as ammonia, nitrites and nitrates. These nitrogen compounds have great interference with fish metabolism, organ morphophysiology since they present thresholds of toxicity and compromise basic vital functions reducing productive performance, which can decrease the rate of dissolved oxygen and the tolerance to diseases leading to high mortality (CARDOSO et al., 2016; CARVALHO et al., 2017; FERREIRA et al., 2018; MARDONES et al., 2018; MOTA et al., 2019;).

In the aquatic environment of fish breeding, the sources of nitrogen compounds may have different origins, such as: i) excretion of cellular catabolites from the metabolism of proteins and nucleic acids; ii) agricultural inputs (nitrogenated fertilizers); iii) aerobic and anaerobic decomposition of organic matter (SILVEIRA et al., 2009; DINIZ et al., 2012; MOTA et al., 2019; MARDONES et al., 2019). The total ammonium is the total sum of ammonium ( $\mathrm{NH}^{+}$) and ammoniac (NH3), protein and nucleic acid matabolism, because of biochemical degradation (XIANG et al., 2016; SHRIVASTAVA et al., 2017; MARDONES et al., 2019).

During the nitrogen cycle, in nature or in the artificial aquatic environment, prokaryotic organisms perform chemical reactions that convert organic compounds into nitrogenous substances, like the: cyanophytes (Nostoc and Nabaema), bacterias and Archaea (Pseudomonas, Azotobacter, Nitrobacter, Methylomonas, Alcaligenes, Thriobacillus, Methanosarcina, Metanococcus, Chromatium, Chlorobium, Desulfovibrio, Clostridium, Rhizobium, Nitrososphaerea , Nitrosopumilus, Frankia,Bacilluscereus,Nitrosomonas and Nitrosospira) and are involved with the various ways in which organic compounds are transformed into ammonia, nitrite and nitrate (BERNHARD, 2010; BASKARAN et al., 2020).

Others naturals processes of molecule transformation in the aquatic environment change abiotic factors such as luminosity, $\mathrm{pH}$, salinity, dissolved oxygen, temperature and electrical conductivity (LOPES et al., 2008; MAKORI et al., 2017; JAHANGIRI et al., 2018). In addition, it is possible to observe the evolution to overpopulations of a given species, causing competition and excessive release of metabolites, contaminating and infesting the environment and fish culture (ZACARDI et al., 2017). Thus, with the practice of growing fish in confinement one should look for alternatives to control these undesirable populations. It is noticed that there will always be a seasonality of the populations, varying according to the environmental conditions of the tank.

Even more relevant, in farms where there is excessive colonization, a process of eutrophication can be initiated leading to the drop of dissolved oxygen and causing morphophysiological changes in the gills, liver and gastrointestinal tract. Cyanobacterial toxins alter the quality of fish meat, changing it to an unpleasant taste, characterized as "clay taste" (MATTHIENSEN et al., 2012).

According to Cyrino et al. (2010); Ferreira et al. (2018) in order to achieve successful production and avoid undesirable conditions during fish farming, it is important to adopt simple water quality management practices. It is necessary to monitor all the limnological factors of the tank, including dissolved oxygen, $\mathrm{pH}$, alkalinity, electrical conductivity, ammonia, nitrites, nitrates, $\mathrm{CO}_{2}$, salinity and temperature (LEIRA et al., 2017). In the same sense, it is important to monitor how fishes are developing, if there are anatomicmorphological changes or histological changes. Essential analyzes for good breeding monitoring are: 
productive performance (morphometry - measures of length, weight, bromotologic of the carcass, hepatosomatic and viscerosomatic fat indexes), water quality (physical-chemical-byological parameters); histomorphometric changes of the gastrointestinal tract.

\section{Considerations about fish morphology and its importance for proper nutritional management}

The Pisces Class predominantly encompasses aquatic, heterothermal animals, with branchial respiration, comprising more than 34,725 , totaling more than $50 \%$ of the total vertebrates on the planet, and each species has developed adaptations to the conditions imposed by the environment (SADO et al., 2020).

There is a consensus in the specialized literature on the organizational similarity and gastrointestinal tract morphology of fish with most known vertebrates (GROSELL et al., 2010; FAGUNDES et al., 2016; BURTON et al., 2018). Ray et al. (2014); Sado et al. (2020) describe that the gastrointestinal tract of fish is basically formed by the mouth, esophagus, stomach, intestine and accessory organs (pancreas, liver and gallbladder), as shown in Figure 1.

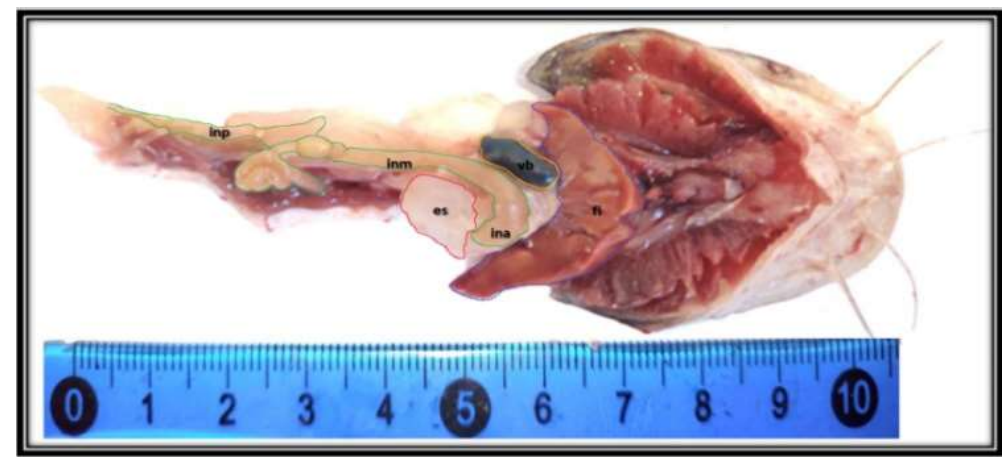

Figure 1: Example of anatomical organization of the gastrointestinal tract of fish and attached organs of Jundiaras stomach (s); (ina) anterior intestine; (inm) medium intestine; (inp) posterior intestine; (vb) gallbladder; (fi) liver.

Ray et al. (2014) demonstrated that the intestine is located just after the esophagus and the stomach (gastric fish). As the length, shape and thickness of the intestine vary according to eating habits, food supply, species and environmental factors, in many species, they start right after the esophagus or others just after the stomach, short or long and are mostly divided into anterior (proximal), medium (medial) and posterior (distal) (Fugura 3), with the initial function of completing the digestion process initiated in the stomach and absorbing nutrients, water and ions, in the proximal region and in the distal the absorption of proteins and peptides, and also intestinal immunological participation, morphology and physiology of the digestive system of fish (GONÇALVES et al., 2012; RAY et al., 2014; COSTA et al., 2015; GONÇALVES et al., 2012; SADO et al., 2020; AMENYOGBE et al., 2020).

The histological characteristics of the fish intestine have been extensively studied, and corroborate that they are very similar in terms of their general organization and the presence of four overlapping extracts (tunics), which may vary for each species, being constituted by enormous cellular diversity (Figure 2A, B), with specialized functions to perform digestive functions and also the formation of barriers against mechanical damage, enzymatic, phagocytic and immunological defense against pathogenic invading agents, osmoregulation, endocrine regulation and reconstruction (cell regeneration) (NASRUDDIN et al. 2014; RAY 
et al., 2014; HAN et al., 2015; BURTON et al., 2018; BHAT et al., 2019; MARTOS-SITCHA et al., 2020).
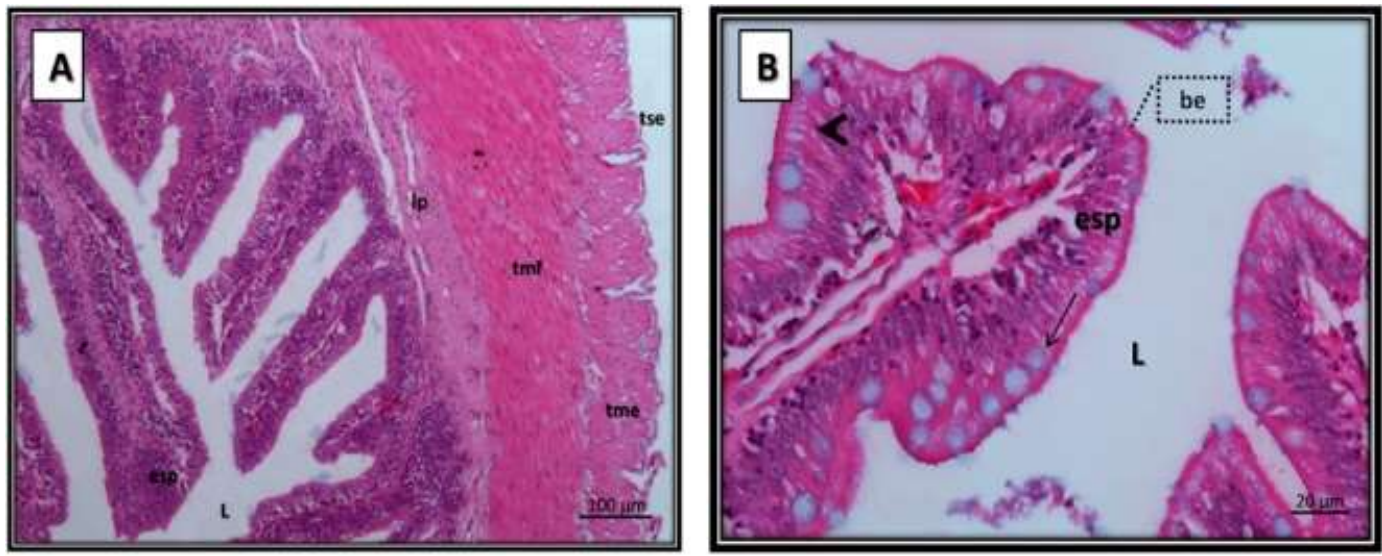

Figure 2 A, B: Histomicrographs of the intestine of jundiaras. (A) panoramic view of the tissues (tunics) of the intestinal tract: (esp) simple prismatic epithelium; (Ip) own blade; muscle tunics - (tmi) internal muscle tunic and (tme) external muscle tunic; (tse) serous tunic. $10 x$ and $40 x$ objectives, $\mathrm{HE} / \mathrm{AB}$.

For these same authors, the tissues that make up the intestinal tract of fish are specialized and efficient in the production of secretions for digestion, absorption of nutrients and defense.

Histologically, the regions of the intestine of teleostic fishes have three different portions, which differ by organization, disposition, thickness, ramifications, heights and length of villi and tunics and, moreover, by the number and cell types (Bhat et al., 2019; Gosavi et al., 2019) (Figures 3 A, B, C).
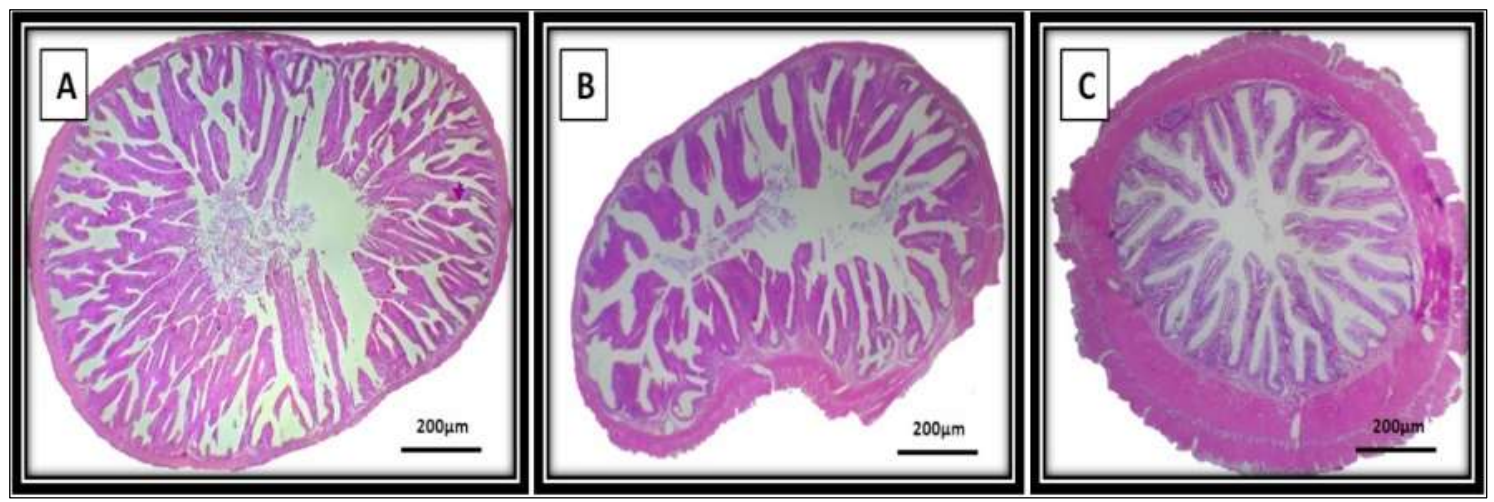

Figures 3 A,B,C: Histomicrographs of the intestine of jundiara showing the differences in intestinal villi by region. (A) anterior; (B) medium; (C) posterior. Objectives: (A), (B), (C) 4x, HE/AB.

\section{Benefits of probiotic supplementation in fish nutrition}

Ferreira et al. (2018); Yang et al. (2019) reinforced that the main changes that probiotics applications promote in fish farming are in the gastrointestinal microbiota of the host, increasing nutrient absorption of the diet, and also enhance the nutritional value and intensify immune responses to pathogen. In this sense, the management of the intestinal microbiota becomes crucial, since besides guaranteeing the combat and prevention of diseases, it potentiates the digestibility and absorption of nutrients, resulting in higher productive performance.

Currently, it is understood that the use of antibiotics in fish farming can generate resistance and this has been discussed in the scientific community, having as an alternative the use of probiotics, because it is a product that involves living microorganisms capable of benefiting the host by improving the balance of the 
intestinal flora and for the prevention of diseases, without risk to man or to the crop itself (FERREIRA, 2014).

\section{Probiotics and environmental health: intestinal morphological and microbiota modulations}

The water used in fish farming comes from a variety of sources: subsoil, rivers, lakes and oceans (ITAUASSÚ et al., 2018). These authors discuss that in closed systems or creations in excavated tanks the main source is the watersheds of the surroundings, and this capture is performed through channels or hydraulic pumps from a source to the tanks.

For Cyrino et al. (2010) the catch is an impactful form of use, but the return of the water is more worrisome, because in the excavated tanks are released the foods that are not totally consumed by the fish, generating leftovers that decant in the bottom, which become part of the chemical composition of dissolved elements in water.

Another important factor, besides food waste, is the excretions released by living organisms, which often become toxic to the fish and to the consumer (TANTITIKITTIT et al., 2005). The compounds that are released in the water are the nitrogen and phosphorus based, due to the metabolism of the protein constituents of the ration (CYRINO et al., 2010).

The tissues that form the intestine of fish are specialized for aquatic feeding (Ferreira et al., 2014) and are molded according to the genetic characteristics of each species and the biological evolution process, but which in artificial environments also suffer from influence by water quality, nutrition and intestinal microbiota, either during ontogenetic development or exposure to these factors in the breeding environment (BEMVENUT et al., 2010; TONI et al., 2017; ORNELAS-GARCÍA et al., 2018; PARRIS et al., 2019; MARTOSSITCHA et al., 2020; PERRY et al., 2020).

It is believed that the use of probiotics can play an important key role in improving water quality and therefore can contribute not only to fish health but also to the environment, as effluents will have a better quality, with a lower presence of harmful organisms and undesirable waste (NAKANDAKARE et al., 2013). The introduction of probiotics in fish diet can be crucial for a fish culture, being a transforming agent and aggregator of water quality, sanity and productive performance.

Many qualitative and quantitative studies have evaluated the use of food additives and the intestinal tract of fish, whether from an anatomical, microscopic (histological) or molecular (histochemical) and microbiological point of view (RAY et al., 2014; ASADUZZAMAN et al., 2018; VAN DOAN et al., 2019; KUEBUTORNYE et al., 2019). For these same authors, at first, the anatomical description can provide information that will better understand the nutritional aspects, such as: types, composition, size of food and how they are processed by the intestinal tract. Each species has its morphological specificities that must be understood for efficient management during fish farming.

In general, it is perceived that it is impossible to separate the factors that influence the environmental, morphological and intestinal microbiota modulations in fish. It is believed that it is necessary to evaluate the morphology, but this together with the presence and knowledge of naturally occurring microorganisms, whether in the water or in the intestine, which are responsible for the appearance of 
diseases or even those that can be potentially beneficial to fish modulating their morphophysiology (BUTT et al., 2019; AMENYOGBE et al., 2020; ABDEL-AZIZ et al., 2020).

The modulation of the microbiota associated with the intestinal tract in teleostic fishes varies according to the conditions of the environment, diet, species of fish, types of colonizing organisms (SOUZA et al., 2020). The regulatory gene expressions of the innate immune system carried out by the host to adaptive conditions of the microbe and population wealth, mainly during ontogenetic development, comprising different phases, as mentioned by Robison et al. (2018); López-Nadal et al. (2020): (i) displacement of microorganisms into the intestinal tract, (2) ecological and adaptive processes of immigrant microbes to the intestinal lumen; (iii) reverse migration of microbes from the fish's intestinal tract to water and (iv) adaptive mechanisms of the microbiota.

The microbial modulation and adaptation in the host's intestine can be evaluated by the rate of microbial growth, abundance and persistence in the intestine or in the environment, varying and starting in the oviposition, larval, juvenile and adult phases, and can be replaced or remain according to the control carried out by the host's adaptive and selective immune system (STEPHENS et al., 2016; LOPEZ-NADAL et al., 2020).

Stagaman et al. (2017); Lopez-Nadal et al. (2020) demonstrated a form of intestinal immunomodulation of the host in the selection of the intestinal microbiota, through the (host) pathways of the selective mechanism of the intestinal microbiota by the host through the presence or absence, synthesis of molecules in the mucosa, proliferation of epithelial cells, leukocyte migration (macrophages) and genes involved, such as: concentrations of lipopolysaccharide and alkaline phosphatase and protective mucin secretion in the apical intestinal epithelium, controlled by transcriptional and translational mechanisms.

The microbiota selected during fish's life is involved in immune defense and response mechanisms to invading agents and also performs several functions, among them the production of enzymes related to digestion (amylase, cellulase, lipase, proteases, chitinase, cellulases, phosphatases, esterases and phytase), cholesterol uptake and volatile fatty acids, fat storage, enzymatic gene suppression and immunostimulation (immuno-inductive activities), hematopoiesis through the ascension, increment, displacement and activation of the lymphoid tissues associated with the gastrointestinal system (GALT), macrophages, lymphocytes (B and T), CD4 T, IgA antibodies and in viral infections and inflammatory processes (WANG et al., 2017; TALWAR et al., 2018; LICKWAR et al., 2017; LOPEZ-NADAL et al., 2020; SOUZA et al., 2020).

Still in the same evaluations are related responses to the following beneficial effects on the hosts: control of pathogenic organisms (bactericidal and bacteriostatic), increased rates of survival, reproduction and growth in the lavatory and juvenile phases, improving health status, preventing vibriosis, altering the microbiota, immunostimulating and increasing chemical constituents, as mentioned in the literature grouped below. Attempts were made to gather the main research on reported species of microorganisms that can be beneficial to host fish as exemplified in Table 2.

Some researches have has directed studies to evaluate the effectiveness of probiotics in fish farming, mainly for the modulation of the intestinal microbiota (AMENYOGBE et al., 2020). For these authors, great 
advances have been achieved, but it requires more studies of its direct effects on the regulatory and control roles of pathogens that affect fish in captivity (LIEKE et al., 2020). Another commonly used medium is the addition to rations of substances that increase immunity and protection, such as vitamin C, immunomodulators ( $\beta$-glucans), (mananoligosaccharides) (GAO et al., 2012), lipids (FALCON et al., 2007) and vitamin E (ZHOU, 2014).

Table 2: Main studies on the use of probiotics in fish farming.

\begin{tabular}{|c|c|c|c|}
\hline FISHES SPECIES & PROBIOTIC USED & RESULTS OBTAINED & REFERENCES \\
\hline $\begin{array}{l}\text { Puntius } \\
\text { gonionotus }\end{array}$ & $\begin{array}{l}\text { Enterobius faecalis, } \\
\text { Lactobacillus } \\
\text { fermentum and } L . \\
\text { mesenteroides }\end{array}$ & Improvement in productive performance & Allameh et al. (2015) \\
\hline $\begin{array}{l}\text { Pseudoplatysto } \\
\text { ma } \\
\text { corruscans e P. } \\
\text { fasciatum }\end{array}$ & Weissella cibaria & $\begin{array}{l}\text { Increase in lactic acid microbiota, inhibition } \\
\text { of pathogenic bacteria (Vibrio ssp and } \\
\text { Pseudomonas ssp) and immunostimulation }\end{array}$ & Mpurino (2012) \\
\hline Cyprinus Carpio & 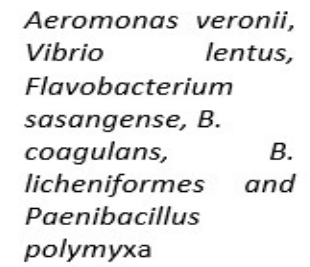 & $\begin{array}{l}\text { Immunomodulation and resistance to } \\
\text { pathogens, increased growth, and resistence } \\
\text { to Aeromonas hydrophila. }\end{array}$ & $\begin{array}{l}\text { Giri et al. (2013); Chi et al. } \\
(2014)\end{array}$ \\
\hline Catla catle & $\begin{array}{l}\text { B. } \\
\text { amyloliquefaciens } e \\
\text { L. planturum }\end{array}$ & $\begin{array}{l}\text { Enhancement of enzyme defenses } \\
\text { (lysozyme), resistance to the activity of } \\
\text { pathogenic bacteria }\end{array}$ & $\begin{array}{l}\text { Das et al. (2013); Gupta et al. } \\
\text { (2014) }\end{array}$ \\
\hline Labeo rohita & $\begin{array}{l}\text { L. acidophilus, L. } \\
\text { bulgaris, L. casei, L. } \\
\text { plantarum, } \\
\text { Bifidobacterium } \\
\text { bifidum, } \\
\text { Saccharomyces } \\
\text { cerevisiae, } \\
\text { faecium, Arpergilus } \\
\text { oryzae, B. subtilis, L. } \\
\text { factis, S. cerevisiae } \\
\text { and L. plantarum }\end{array}$ & $\begin{array}{l}\text { Increased growth and survival rate, } \\
\text { immunostimulation and production of } \\
\text { digestive enzymes }\end{array}$ & $\begin{array}{l}\text { Mohapatra et al. (2014); Jha et } \\
\text { al. (2015); Kumar et al. (2019) }\end{array}$ \\
\hline $\begin{array}{l}\text { Ctenopharyngo } \\
\text { don idellus }\end{array}$ & $\begin{array}{l}\text { S. xiamenensis (A1 e } \\
\text { A2) and A. veroni }\end{array}$ & $\begin{array}{l}\text { Increased respiratory metabolism, } \\
\text { phagocytic activities, enzyme defense } \\
\text { (lysozyme) and pathology control }\end{array}$ & Wu et al (2015) \\
\hline $\begin{array}{l}\text { Oncorhynhus } \\
\text { mykiss }\end{array}$ & $\begin{array}{l}\text { Lactococcus spp; } E \text {. } \\
\text { casseliflavus and } L \text {. } \\
\text { loctis, Pediococcus } \\
\text { acidilactici and } \\
\text { Saccharomyces } \\
\text { cerevisiae }\end{array}$ & $\begin{array}{l}\text { Growth inhibition of } L \text {. garvieae, } \\
\text { immunological modulation and resistance to } \\
\text { infection and increased enzyme activities, } \\
\text { promoted growth, molecular modulation } \\
\text { and microbiota modulation }\end{array}$ & $\begin{array}{l}\text { Araújo et al. (2015); Safari et } \\
\text { al. (2016); Araújo et al. (2016); } \\
\text { Nguyen et al (2017); Huyben et } \\
\text { al. (2018) }\end{array}$ \\
\hline $\begin{array}{l}\text { Oreochromis } \\
\text { niloticus }\end{array}$ & $\begin{array}{l}\text { B. subtilis, } \\
\text { Cordyceps militari, } \\
\text { L. plantarum and, B. } \\
\text { velezensis }\end{array}$ & $\begin{array}{l}\text { Improvement in ovoposition and embryonic } \\
\text { development, survival rate of fry and } \\
\text { Increased immunostimulation } \\
\text { productive performance }\end{array}$ & $\begin{array}{l}\text { Van Doan et al. (2017); Van } \\
\text { Doan et al. (2018); Dias et al. } \\
(2020)\end{array}$ \\
\hline $\begin{array}{l}\text { Centropomus } \\
\text { undecimalis }\end{array}$ & $\begin{array}{l}\text { B. licheniformis and } \\
\text { B. } \\
\text { amyloliquefaciens } \\
\text { and Bacillus sp }\end{array}$ & $\begin{array}{l}\text { Better development, immunity and } \\
\text { modulation of the gastrointestinal tract, } \\
\text { inhibition of opportunistic bacteria and } \\
\text { improvements in water quality parameters }\end{array}$ & Tarnecki et al. (2019) \\
\hline Tor tambroides & $\begin{array}{l}\text { Alcaligenes } \\
\text { Bacillus sp. }\end{array}$ & $\begin{array}{l}\text { Modulation of microbiota and intestinal } \\
\text { histomorphology } \\
\text { Increased mucosal and serum immunity, } \\
\text { disease resistance and performance }\end{array}$ & Asaduzzaman et al. 2018. \\
\hline
\end{tabular}




\begin{tabular}{|c|c|c|c|}
\hline $\begin{array}{l}\text { Scophthaimus } \\
\text { maximus }\end{array}$ & $\begin{array}{l}\text { Psychrobacter spp., } \\
\text { Staphylococcus, } \\
\text { Saprophyticus, } \\
\text { Acinetobacter } \\
\text { hoemolyticus. }\end{array}$ & Improvement in productive performance & Wanka et al. 2019 \\
\hline $\begin{array}{l}\text { Trochinotus } \\
\text { ovatus }\end{array}$ & B. pumilus & $\begin{array}{l}\text { Improvement in growth, immune status and } \\
\text { resistance to diseases caused by } T \text {. ovatus }\end{array}$ & Liu et al. 2019 \\
\hline Arapaima gigas & $\begin{array}{l}\text { Enterococcus } \\
\text { faecium }\end{array}$ & $\begin{array}{l}\text { Modified the intestinal microbiota, improve } \\
\text { growth performance and hematology and } \\
\text { reduce parasitic load }\end{array}$ & Costa Sousa et al. (2019) \\
\hline Danio rerio & $\begin{array}{l}\text { Lactobacillus sp and } \\
\text { B. } \\
\text { amyloliquefaciens }\end{array}$ & $\begin{array}{l}\text { Modulation of the microbiota and relief of } \\
\text { intestinal metabolic disorders and Reduction } \\
\text { of hepatic oxidative stress and immunity } \\
\text { against Aeromonas hydrophila and } \\
\text { Streptococcus agalactia }\end{array}$ & $\begin{array}{l}\text { Zang et al. (2018); Lin et al. } \\
\text { (2019) }\end{array}$ \\
\hline $\begin{array}{l}\text { Pseudoplatysto } \\
\text { ma } \\
\text { corruscans } \times P \\
\text { reticulatum }\end{array}$ & $\begin{array}{l}\text { B. subtilis and } \\
\text { Weissella cibaria }\end{array}$ & $\begin{array}{l}\text { Improvement in productive performance, } \\
\text { immune system and height and width of } \\
\text { intestinal villi, increases the number of } \\
\text { thrombocytes and the concentration of } \\
\text { lysozyme }\end{array}$ & $\begin{array}{l}\text { Pereira et al. (2016); Veiga et } \\
\text { al., (2020) }\end{array}$ \\
\hline $\begin{array}{l}\text { Oreochromis } \\
\text { niloticus (var. } \\
\text { GIFT) }\end{array}$ & $\begin{array}{l}\text { B. toyoi and B. } \\
\text { subtilis }\left(\mathrm{PAS} \mathrm{TR}^{\odot}\right)\end{array}$ & $\begin{array}{l}\text { Modulation of the intestinal microbiota, } \\
\text { increased immunity and morphological } \\
\text { modulation }\end{array}$ & Nakandakare et al. (2018) \\
\hline Pagrus major & B. subtilis & $\begin{array}{l}\text { Increased performance and improved } \\
\text { digestive enzyme reactions } \\
\text { amylase, protease and lipase) }\end{array}$ & Zaineldin et al. (2018) \\
\hline $\begin{array}{l}\text { Epinephelus } \\
\text { fuscoguttatus } \times \\
\text { E. lanceolatus }\end{array}$ & B. subtilis & $\begin{array}{l}\text { Increased immune responses to viruses, } \\
\text { enzyme activities of lizoenzymes and serum } \\
\text { bactericidal activity }\end{array}$ & Zhou et al. (2018) \\
\hline
\end{tabular}

The understanding of the mechanisms of action of food additives used in fish farming is still a challenge to be overcome, with the aim of improving and quantity of production, minimizing negative impacts due to the indiscriminate supply, especially antibiotics (AMENYOGBE et al. 2020). Knowledge of the morphophysiology and conditions of the gastrointestinal microbiome of fish provides alternatives for the management of pathologies that cause damage to production and health conditions (LIEKE et al., 2020).

The mechanisms of action of food additives on the physiology of fish involve processes of morphological, molecular and microbiota modulations (DEVI et al., 2017; ASADUZZAMAN et al., 2018; KUMAR et al., 2019; VAN DOAN et al., 2019; KUEBUTORNYE et al., 2019) (Figure 4).

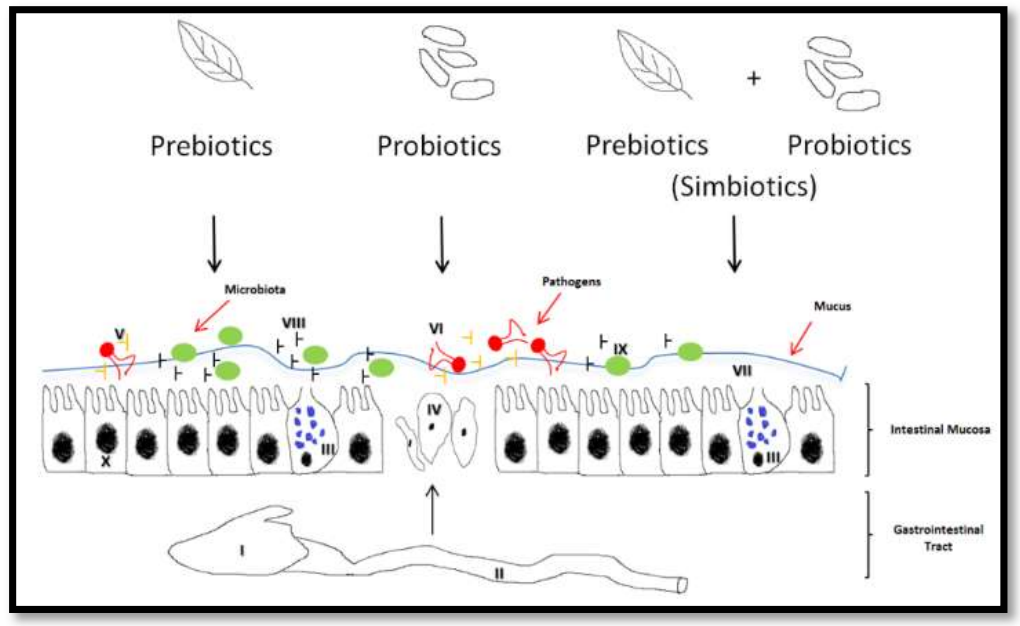

Figure 4: Illustrative showing mechanisms of action for the use of prebiotics, probiotics and symbiotics in the intestinal tract of fish. (I) stomach; (II) intestine; (III) goblet cells; (IV) claviform cells; (V) toxins; (VI) pathogens; (VII)

mucus; (VIII) defense molecules; and (IX) intestinal microorganisms. Source: Adapted Beck et al. (2015).

Defense systems in fish are formed by several distinct and interdependent components (Esteban et al. 2012). In this sense, several studies carried out by Esteban (2012); Hafez et al. (2013); Sayyaf-Dezfulia et al. (2018); Lieke et al. (2020) demonstrated several innate and adaptive forms of defense in fish, such as physical barriers in the gills, skin, scales and gastrointestinal tract. Biller-Takahashi et al. (2014) report the 
importance of defense systems in fish and highlight that mucosecretory products are synthesized in fish lymphoid tissues (macrophages, lymphocytes, mast cells and granulocytes), which have many soluble components, such as lysozymes and immunoglobulins, functioning as immune memory processors.

Much research has been describing defenses in fish organs and tissues (Biller-Takahashi et al. (2014). According to these authors, the dermis, intestinal epithelium, kidneys, spleen, liver, and gills are responsible for mucosecretion (production of mucins) through of goblet cells ('globlet cells'), which act as a natural, physical, biochemical, dynamic and semi-permeable barrier, as well as exchanges of nutrients, osmoregulation, water, gases, odors, hormones.

\section{CONCLUSIONS}

The practice of fish farming is a potential strategy for environmental conservation, since it contributes to the reduction of capture fisheries. Given the historic increase in the demand for fish meat consumption, production using traditional methods is unsustainable to meet consumers' wishes. In addition, the production of meat and derivatives are direct results of the environment, which can compromise the quality of food, sanitary conditions, maximize the appearance of diseases, resistance to antibiotics and excessive use of water.

As an alternative to improving the production and maintenance of the environmental balance, the addition of probiotics is an alternative that minimizes the damages caused by the production systems. Studies reveal that the benefits are infinite, but they require more investments in training, research and extension, aiming to popularize and stimulate the use.

It is understood that the suitability of ecological management practices, correct feeding, monitoring of water quality and probiotics associated with fish nutrition, it will be possible to approach the maximum sustainability and quality of the cultivated fish.

ACKNOWLEDGMENTS: To the Catholic University Dom Bosco (UCDB), to the Coordination of Improvement of Personnel of Higher Education (CAPES) for scholarship, Federal Institute of Mato Grosso and Mato Grosso do Sul (IFMT and IFMS) and State University of Mato Grosso do Sul.

\section{REFERENCES}

ABDEL-AZIZ, M.; BESSAT, M.; FADEL, A.; ELBLEHI, S.. Responses of dietary supplementation of probiotic effective microorganisms (EMs) in Oreochromis niloticus on growth, hematological, intestinal histopathological, and antiparasitic activities. Aquaculture International, v.28, p.947-963, 2020. DOI: https://doi.org/10.1007/s10499-019-00505-z

AKANMU, O. A.. Probiotics, an Alternative Measure to Chemotherapy in Fish Production. INTECHOPEN, 2018. DOI: http://dx.doi.org/10.5772/intechopen.72923

ALLAMEH, S. K.; RINGO, E.; YUSOFF, F. M.; DAUD, H. M.; IDERIS, A.. Dietary supplementation of Enterococcus faecalis on digestive enzyme activities, short chain fatty acid roduction, immune system response and disease resistance of Javanese carp (Puntius gonionotus Bleeker 1850), Aquac. Nutr., v.23, 331-338, 2015. DOI: https://doi.org/10.1111/anu.12 397

ALLAMEH, S. K.; NOAMAN, V.; NAHAVANDI, R.. Effects of Probiotic Bacteria on Fish Performance. Adv Tech Clin Microbiol., v.1, n.2, 2017.

AMENYOGBE, E.; CHEN, G.; WANG, Z.; HUANG, J.; HUANG, B.; LI, H.. The exploitation of probiotics, prebiotics and synbiotics in aquaculture: present study, limitations and future directions: a review. Aquaculture International, v.28, p.1017-1041, 2020. DOI: https://dx.doi.org/10.1007/s104 
99-020-00509-0

ANA. Agência Nacional das Águas. Art. 9o, Lei n. 9.433, de 1997. Enquadramento: Bases Conceituais. ANA, 1997.

ANA. Agência Nacional das Águas. Enquadramento: Bases Conceituais. Resolução n. 357/2005. Brasília: ANA, 2005.

ARAÚJO, C. S. O.; TAVARES-DIAS, M.; GOMES, A. L. S. Infecções parasitárias e parâmetros sanguíneos in Arapaima gigas Schinz, 1822 (Arapaimidae) cultivados no estado do Amazonas, Brasil. In: TAVARES-DIAS, M.. Manejo e Sanidade de peixes in cultivo. Macapá: Inbrapa Amapá, 2009. p.389424.

ARAÚJO, C.; MUÑOZ-ATIENZA, E.; NAHUELQUÍN, Y.; POETA, P.; IGREJAS, G.; HERNÁNDEZ, P.E.; CINTAS, L. M.. Inhibition of fish pathogens by the microbiota from rainbow trout (Oncorhynchus mykiss, Walbaum) and rearing environment. Anaerobe, v.32, p.7-14, 2015. DOI: https://dx.doi.org/10.1016/j.anaerobe.2014.11.001

ARAÚJO, C.; MUÑOZ-ATIENZA, E.; POETA, P.; IGREJAS, G.; HERNÁNDEZ, P.; HERRANZ, C.; CINTAS, L.. Characterization of Pediococcus acidilactici strains isolated from rainbow trout (Oncorhynchus mykiss) feed and larvae: safety, DNA fingerprinting, and bacteriocinogenicity. Diseases of Aquatic Organisms, v.119, n.2, p.129-143, 2016. DOI: https://dx.doi:10.3354/dao02992

ASADUZZAMAN, M.; SOFIA, E.; SHAKIL, A.; HAQUE, N. F.; KHAN, M. N. A.; IKEDA, D.; ABOL-MUNAFI, A. B.. Host gutderived probiotic bacteria promote hypertrophic muscle progression and upregulate growth-related gene expression of slow-growing Malaysian Mahseer Tor tambroides. Aquaculture Reports, v.9, p.37-45, 2018. DOI: https://doi.org/101 6/j.aqrep.2017.12.001

BACCI, D. C.; PATACA, E. M.. Educação para a água. Estud. Avançados, São Paulo, v.22, n.63, p.211-226, 2008.

BANDEIRA, M. G. A.; NASCIMENTO, J. S.. Estudo prospectivo relativo à atividade da tilápia para a indústria de alimentos no período de 2006 a 2016. Cad. Prospec., Salvador, v.10, n.3, p.552-562, 2017.

BARBOSA, J. A.; SANTANA, A. C.; SILVA, I. M.; BOTELHO, M. N.; CONDURÚ NETO, J. M. H.. Características comportamentais do consumidor de peixe no mercado de Belém. Revista Tropical Journal of Fisheries and Aquatic Sciences, Belém, v.7 n.1, p.115-133, 2006.

BARRETO, B. A. P.. Microbioma and probiotics: from gut to Mars. Brazilian Journal of Otorhinolaryngology, v.84 n.1, p.1-2, 2018

BARROS, I. F.. O agronegócio e a atuação da burguesia agrária: considerações da luta de classes no campo. Serv. Soc. Soc., São Paulo, v.131, p.175-195, 2018.

BECK, B. H.; PEATMAN, E.. Mucosal Health in Aquaculture. Cambridge: Academic Press, 2015.

BEMVENUTI, M. A.; FISCHER, L. G.. Peixes: morfologia e adaptações. Cadernos de Ecologia Aquática, v.5, n.2, p.3154, 2010.
BERNHARD, A.. The nitrogen cycle: processes, players, and human impact. Nature Education Knowledge, v.3, n.10, p.25, 2010.

BHAT, M. Y.; CHANNA, A.; PARAY, B. A.; AL-SADOON, M. K.; RATHER, I. A.. Morphological study of the gastrointestinal tract of the snow trout, Schizothorax esocinus (Actinopterygii: Cypriniformes). Zoologia, Curitiba, v.36, 2019. DOI: https://doi.org/10.3897/zoologia.36.e31791

BILLER-TAKAHASHI, J. D.; URBINATI, E. C.. Fish Immunology. The modification and manipulation of the innate immune system: Brazilian studies. Anais Da Academia Brasileira de Ciências, v.86, n.3, p.1484-1506, 2014. DOI: https://doi.org/10.1590/0001-3765201420130159

BISWAS, P. C.; SULTANA, S.; KABIRAJ, M.; HOSSAIN S. M. S.. Role of probiotics in aquaculture practice of Satkhira region of Bangladesh. International Journal of Fisheries and Aquatic Studies, n.7, n.C, p.174-181, 2019. DOI: http://dx.doi.org/10.22271/fish

BRASIL. Ministério da Agricultura, Pecuária e Abastecimento. Instrução normativa n.13/2004. Brasília: MAPA, 2004.

BRASIL. Decreto n. 6.899, DE 15 de July de 2009.

Composição do Conselho Nacional de Controle de Experimentação Animal - CONCEA. Brasília: DOU, 2009.

BRASIL. Ministério da Ciência, Tecnologia e Inovação. Conselho Nacional de Controle de Experimentação Animal. Diretriz da Prática de Eutanásia. Anexo I. Brasília: CONCEA, 2019.

BRITO, J. M.; FERREIRA, A.; HOSMYLTON, C.. Desempenho zootécnico de juvenis de Tilápias do Nilo (Oreochromis niloticus) alimentados com cepas probióticas e submetidos a desafio sanitário. Ciênc. Anim. Bras., v.20, 2019.

BURTON, D.; BURTON, M.. Essential fish biology: diversity, structure and function. Ondres: Oxford University Press, 2018.

BUTT, R. L.; VOLKOFF, H.. Gut Microbiota and Energy Homeostasis in Fish. Frontiers in Endocrinology, v.10, 2019. DOI: https://doi.org/10.3389/fendo.2019.00009

CAO, H.; YU, R.; ZHANG, Y.; HU, B.; JIAN, S.; WEN, C.; YANG, G.. Effects of food supplementation with $\beta$ - glucan and Bacillus subtilis on growth, fillet quality, immunological capacity and antioxidant status of raw Pengze carp (Carassius auratus var. Pengze). Aquaculture, v.508, p.106112, 2019. DOI: https://doi.org/10.1016/j.aquaculture.2019.04.064

CARDOSO, A. S.; EL-DEIR, S. G.; CUNHA, M. C. C.. Bases da sustentabilidade para atividade de piscicultura no semiárido de Pernambuco. Interações, Campo Grande, v.7, n.4, p.645653, 2016.

CARDOSO FILHO, F. C.; ALVES, V. C.; LIMA, C. E.; GUIMARÃES, C. M. M.; PEREIRA, M. M. G.; MURATORI, M. C. S.. Qualidade higiênico-sanitária da ração utilizada in piscicultura. Rev. Inst. Adolfo Lutz, São Paulo, v.70, n.3, 2011.

CARDOSO, E. N.; FERMINO, F. S.. Águas Subterrâneas. 
Associação Brasileira de Águas Subterrâneas. Seção Estudos de Caso e Notas Técnicas, 2018.

CARVALHO, M. A. G.; CARVALHO, M. A. G.; FERNANDES, L. F. L.; GOMES, L. C.. Digestibility, protein retention rate and ammonia excretion in juvenile fat snook (Centropomus parallelus) fed with different protein levels. Cienc. Rural, Santa Maria, v.47, n.7, 2017.

CAVALHEIRO, A. C. M.; CASTRO, M. L. S.; EINHARDT, M. D. S.; POUEY, J. L. O. F.; PIEDRAS, S. N.; XAVIER, E. G.. Microingredientes utilizados in alimentação de peixes in cativeiro - Revisão. Revista Portuguesa de Ciências Veterinárias, v.109, p.589-590, p.11-20, 2014

CHANDRAKALA, N.; SOUNDHARANAY- AKI, G.. Role of Probiotics in aquaculture- a review. International Journal of Current Innovation Research, v.3, n.2, p.577-582, 2017.

COPPOLA, M. M.; TURNES, C. G.. Probióticos e resposta imune Mario de Menezes. Ciência Rural, Santa Maria, v.34, n.4, p.1297-1303, 2004.

COSTA SOUSA, N.; COUTO, M. V. S.; ABE, H. A.; PAIXÃO, P. E. G.; CORDEIRO, C. A. M.; MONTEIRO LOPES, E.; FUJIMOTO, R. Y.. Effects of an Enterococcus faecium -based probiotic on growth performance and health of Pirarucu, Arapaima gigas. Aquaculture Research, v.50, p.3720-3728, 2019. DOI: https://doi.org/10.1111/are.14332

CRUZ, M. F. G.; BORDINHON, A. M.. Environmental impacts and conservation of natural resources associated with family aquaculture of Humaitá/AM: from the environmental licensing to the use of natural resources. Revista Educação Ambiental in Ação, v.17, n.65, 2018.

CYRINO, J. E. P.; BICUDO, Á. J. A.; SADO, R. Y.; BORGHESI, R.; DAIRIKI, J. K.. Piscicultura e o ambiente: o uso de alimentos ambientalmente corretos in piscicultura. R. Bras.

Zootec., Viçosa, v.39, p.68-87, 2010.

DABROWSKI, K.; PORTELLA, M. C.. Feeding Plasticity and Nutritional Physiology in Tropical Fishes. The Physiology of Tropical Fishes, p.155-224, 2005. DOI: https://doi:10.1016/s1546-5098(05)21005-1

DAGA, V. S.; GUBIANI, É. A.; CUNICO, A. M.; BAUMGARTNER, G.. Effects of abiotic variables on the distribution of fish assemblages in streams with different anthropogenic activities in Southern Brazil. Neotropical Ichthyology, v.10, n.3, p.643-652, 2012. DOI: https://dx.doi.org/10.1590 $\angle S 1679-62252012000300018$

DAS, A.; NAKHRO, K.; CHOWDHURY, S.; KAMILYA, D.. Effects of potential probiotic Bacillus amyloliquifaciens FPTB16 on systemic and cutaneous mucosal immune responses and disease resistance of catla (Catla cat/a). Fish $\&$ Shellfish Immunology, v.35, n.5, p.1547-1553, 2013. DOI: https://doi.org/10.1016/j.fsi.2013.08.022

DEROME, N.; FILTEAU, M.. A continuously changing selective context on microbial communities associated to fish, from egg to fork. Evolutionary Applications, v.13, n.6, 2020. DOI: https://doi.org/10.1111/eva.13027

DEVI, E. L.; KUMAR, S.; SINGH, T. B.; SHARMA, S. K.; BEEMROTE, A.; DEVI, C. P.; WANI, S. H.. Adaptation
Strategies and Defence Mechanisms of Plants During Environmental Stress. Medicinal Plants and Environmental Challenges, p.359-413, 2017. DOI:

https://doi.org/10.1007/978-3-319-68717-9 20

DHARMAKAR, P.; ANJUSHA, K. V.. Assessment of Probiotic in Aquaculture: Functional Changes and Impact on Fish Gut. Microbiology Research Journal International, v.29, n.1, p.110, 2019. DOI:

https://doi.org/10.9734/mrii/2019/v29i130156

DIAS, D. C.; FURLANETO, F. P. B.; SUSSEL, F. R.; TACHIBANA, L.; GONÇALVES, G. S.; ISHIKAWA, C. M.; NATORI, M. M.; RANZANI-PAIVA, M. J. T.. Economic feasibility of probiotic use in the diet of Nile tilapia, Oreochromis niloticus, during the reproductive period. Acta Scientiarum. Animal

Sciences, v.42, 2020. DOI: https://dx.doi.org/10.4025/actascianimsci.v42i1.47960

DIEGUES, A. C.. Para uma aquicultura sustentável do Brasil. Banco Mundial/FAO. São Paulo: USP, 2006.

DINIZ, N. M.; HONORATO, C. A.. Algumas alternativas para diminuir os efeitos do estresse em peixes de cultivo revisão. Arq. Ciênc. Vet. Zool. UNIPAR, Umuarama, v.15 n.2, p.149-154, 2012.

ESTEBAN, Á. M.. An overview of the immunological defenses in fish skin. ISRN Immunology, p.1-29, 2012. DOI: https://dx.doi.org/10.5402/2012/853470

FAGUNDES, K. R. C.; ROTUNDO, M. M.; MARI, R. B. Morphological and histochemical characterization of the digestive tract of the puffer fish Sphoeroides testudineus (Linnaeus 1758) (Tetraodontiformes: Tetraodontidae). Anais da Academia Brasileira de Ciências, v.88, n.3, p.1615-1624, 2016. DOI: https://dx.doi.org/10.1590/0001$\underline{3765201620150167}$

FALCON, D. R.; BARROS, M. M.; PEZZATO, L. E.; VALLE, J. B.. Lipídeo e vitamina $C$ in dietas preparatórias de inverno para tilápias-do-Nilo. R. Bras. Zootec., Viçosa, v.36, n.5, p.1462$1472,2007$.

FAO. Food and Agriculture Organization United Nation. Organização das Nações Unidas. The state of world fisheries and aquaculture. FAO, 2018.

FERNANDES, I. M.; BASTOS, Y. F.; BARRETO, D. S.; LOURENÇO, L. S.; PENHA, J. M.. The efficacy of clove oil as an anaesthetic and in euthanasia procedure for small-sized tropical fishes. Braz. J. Biol., São Carlos, v.77, n.3, p.444450, 2017. DOI: http://dx.doi.org/10.1590/15196984.15015/

FERREIRA, G. S.. Disbiose intestinal: aplicabilidade dos prebióticos e dos probióticos na recuperação e manutenção da microbiota intestinal. Monografia (Bacharelado) - Centro Universitário Luterano, Palmas, 2014.

FERREIRA, A. H. C.; LOPES, J. B.; ARARIPE, M. N. B. A.; MONTEIRO, C. A. B.; ANDRADE, F. T.. Avaliação do efeito da adição de probiótico na dieta de alevinos e juvenis de tilápias-do-nilo (Oreochromis niloticus) criados em esgoto doméstico tratado. Eng. Sanit. Ambient., v.23, n.4, p.665674, 2018. DOI: http://dx.doi.org/10.1590/S141341522018134833 
FIGUEIRÓ, C. S. M.; OLIVEIRA, D. B.; RUSSO, M. R.; CAIRES, A. R. L.; ROJAS, S. S.. Fish farming water quality monitored by optical analysis: The potential application of UV-Vis absorption and fluorescence spectroscopy. Aquaculture, v.490, p.91-97, 2018.

FLICK, U.. Introdução à metodologia de pesquisa: um guia para iniciantes. Porto Alegre: Penso, 2013.

FUJIMOTO, R. Y.; MACIEL, P. O.; DIAS, M. T.; IWASHITA, M. K. P.; MORAIS, M. S.; ESCONDER, D. M. V.; SOUSA, N. C.; COUTO, M. V. S.; MENESES, J. O.; CUNHA, F. S.; BOIJINK, C.. Anestesia por aspersão de eugenol nas brânquias de peixes como alternativa para estudos de parasitos. Relatório Técnico 180. INBRAPA, 2015.

FULLER, R.. Probiotics in man and animals. Journal of Applied Bacteriology, v.66, p.365-378, 1989.

GAO, J.; KOSHIO, S.; ISHIKAWA, M.; YOKOYAMA, S.; NGUYEN, B. T.; MAMAUAG, R. E.. Effect of dietary oxidized fish oil and vitamin $C$ supplementation on growth performance and reduction of oxidative stress in Red Sea Bream Pagrus major. Aquaculture Nutrition, v.19, p.35-44, 2013.

GARUTTI, V.. Piscicultura Ecológica. São Paulo: EdUNESP, 2003.

GATESSOUPE, F. J.. The use of Probióticos in aquaculture: a review. Aquaculture, v.180, p.147-165, 1999.

GEBREKIROS, S. T.. Factors Affecting Stream Fish Community Composition and Habitat Suitability. J. Aquac. Mar. Biol., v.4, n.2, 2016. DOI:

https://doi.org/10.15406/jamb.2016.04.00076

GIL, A. C.. Métodos e técnicas de pesquisa social. 6 ed. São Paulo: Atlas, 2008.

GIRI, S. S.; SUKUMARAN, V.; OVIYA, M.. Potential probiotic Lactobacillus plantarum VSG3 improves the growth, immunity, and disease resistance of tropical freshwater fish, Labeo rohita. Fish \& Shellfish Immunology, v.34, n.2, p.660666, 2013. DOI: https://doi.org/10.1016/i.fsi.2012.12.008

GONÇALVES, L.; RODRIGUES, U. A. P. O.; MORO, G. V.; CARGNIN-FERREIRA, E. J.; CYRINO, E. P.. Morfologia e Fisiologia do Sistema Digestório de Peixes. In: FRACALOSSI, D. M.; CYRINO, J. E. P.. Nutriaqua: Nutrição e alimentação de espécies de interesse para a aquicultura brasileira. Florianópolis: Sociedade Brasileira de Aquiculura e Biologia Aquática, 2012. p.375.

GOSAVI, S. M.; VERMA, C. R.; KHARAT, S. S.; PISE, M.; KUMKAR, P.. Structural adequacy of the digestive tract supports dual feeding habit in catfish Pachypterus khavalchor (Siluriformes: Horabagridae). Acta Histochemica, v.121, n.4, p.437-449, 2019. DOI:

https://doi.org/10.1016/j.acthis.2019.03.006

GROSELL, M.; FARRELL, A. P.; BRAUNER, C. J.. A continuously changing selective context on microbial communities associated with fish, from egg to fork. Evolutionary Applications, v.30, p.1-55, 2010. DOI: https://doi.org/10.1016/S1546-5098(10)03001-3
GUPTA, A.; GUPTA, P.; DHAWAN, A.. Dietary supplementation of probiotics affects growth, immune response and disease resistance of Cyprinus carpio fry. Fish \& Shellfish Immunology, v.41, n.2, p.113-119, 2014. DOI: https://doi.org/10.1016/j.fsi.2014.08.023

HAFEZ, E. A. A. E.; MOKHTAR, D. M.; ABOU-ELHAMD, A. S.; HASSAN, A. H. S.. Comparative histomorphological Studies on Oesophagus of Catfish and Grass Carp. Journal of Histology, 2013. DOI: https://doi.org/10.1155/2013/858674

HAN, B.; LONG, W.; HE, J.; LIU, Y.; SI, Y.; TIAN, L.. Effects of dietary Bacillus licheniformis on growth performance, immunological parameters, intestinal morphology and resistance of juvenile Nile tilapia (Oreochromis niloticus) to challenge infections. Fish \& Shellfish Immunology, v.46, n.2, p.225-231, 2015. DOI: https://doi.org/10.10 16/j.fsi.2015.06.018

HUYBEN, D.; SUN, L.; MOCCIA, R.; KIESSLING, A.; DICKSVED, J.; LUNDH, T.. Dietary live yeast and increased water temperature influence the gut microbiota of rainbow trout. Journal of Applied Microbiology, v.124, n.6, p.1377-1392, 2018. DOI: https://doi.org/10.1111/jam.13738

HUSSAN, A.; CHOUDHURY, T. G.; VINAY, T. N.; SANJAY, K.; GUPTA, S.. Common problins in aquaculture and their preventive measures. Aquaculture Times, v.2, n.5, p.7-9, 2016.

ITAUASSÚ, D. R.'; SPERA, S. T.. Abordagem prática do dimensionamento da demanda hídrica in projetos de piscicultura. EMBRAPA, 2018.

JAHANGIRI, L.; ESTEBAN, M. Á.. Administration of Probiotics in the Water in Finfish Aquaculture Systems: A Review. Fishes, v.3, n.33, 2018.

JAMI, M. J.; KENARI, A. A.; PAKNEJAD, H.; MOHSENI, M. Effects of dietary b-glucan, mannan oligosaccharide, Lactobacillus plantarum and their combinations on growth performance, immunity and immune related gene expression of Caspian trout, Salmo trutta caspius (Kessler, 1877). Fish Shellfish Immunology, v.11, n.91, p.202-208, 2019.

JATOBÁ, A.; MORAES, K. N.; RODRIGUES, E. F.; VIEIRA, L. M.; PEREIRA, M. O.. Frequency in the supply of Lactobacillus influence its probiotic effect for yellow tail lambari. Ciência Rural, Santa Maria, v.48, n.10, 2018.

JHA, D. K.; BHUJEL, R. C.; ANAL, A. K.. Dietary supplementation of probiotics improves survival and growth of Rohu (Labeo rohita Ham.) hatchlings and fry in outdoor tanks. Aquaculture, v.435, p.475-479, 2015. DOI: https://doi.org/10.1016/i.aquaculture.2014.10.026

KOUSAR, R.; SHAFI, N.; ANDLEEB, S.; ALI, N. M.; AKHTAR, T.; KHALID, S.. Assessment and incidence of fish associated bacterial pathogens at hatcheries of Azad Kashmir, Pakistan. Brazilian Journal of Biology, 2019. DOI: https://doi.org/10.1590/1519-6984.217435

KUBITZA, F.. Tilápia: tecnologia e planejamento na produção comercial. 2 ed. Jundiaí, 2011. 
KUEBUTORNYE, F. K. A.; ABARIKE, E. D.; LU, Y.. A review on the application of Bacillus as probiotics in aquaculture. Fish \& Shellfish Immunology, v.87, p.820-828, 2019. DOI: https://doi.org/10.1016/j.fsi.2019.02.010

KUMAR, P.; KAUR, V. I.; TYAGI, A.; NAYYAR, S.. Probiotic Potential of Putative Lactic Acid Bacteria Isolated from the Fish Gut: Immune Modulation in Labeo rohita (Ham.). In: JITHENDRAN, K. P.; SARASWATHY, R.; BALASUBRAMANIAN, C. P.; VASAGAM, K. P. K.; JAYASANKAR, V.; RAGHAVAN, R.; ALAVANDI, S. V.; VIJAYAN, K. K.. BRAQCON2019: World Conference on Aquaculture in Brackish Water. Journal of Coastal Research, Coconut Creek, v.86, p.119-127, 2019. DOI: https://doi.org/10.2112/SI86-018.1

LEIRA, M. H.; CUNHA, L. T.; BRAZ, M. S.; MELO, C. C. V.; BOTELHO, H. A.; REGHIM, L. S.. Qualidade da água e seu uso in pisciculturas. PUBVET, v.11, n.1, p.11-17, 2017.

LICKWAR, C. R.; CAMP, J. G.; WEISER, M. L. C. J.; KINGSLEY, D. M.; FUREY, T. S.; SHEIKH, S. Z.. Genomic dissection of conserved transcriptional regulation in intestinal epithelial cells. PLOS Biol., v.15, 2017. DOI: https://doi.org/10.1371/journal.pbio.2002054

LIEBEL, S.; TOMOTAKE, M. E. M.; RIBEIRO, C. A. O.. Fish histopathology as biomarker to evaluate water quality. Ecotoxicol. Environ. Contam, v.8, n.2, 2013.

LIEKE, T.; MEINELT, T.; HOSEINIFAR, S. H.; PAN, B.; STRAUS, D. L.; STEINBERG, C. E. W.. Sustainable aquaculture requires environmental-friendly treatment strategies for fish diseases. Reviews in Aquaculture, v.12, p.943965, 2020. DOI: https://doi.org/10.1111/raq.12365

LIMA, K. F.; MATOS, M. B.; RABELLO, W. S.; PEREIRA JUNIOR G.. Avaliação da qualidade da água para tilápias criadas em viveiros escavados no instituto federal fluminense (IFF) Campus Cambuci. In: ZUFFO, A. M.. Aquicultura e pesca: adversidades e resultados. Ponta Grossa: Atena, 2019. p.1-6.

LIN, Y. S.; SAPUTRA, F.; CHEN, Y. C.; HU, S. Y.. Dietary administration of Bacillus amyloliquefaciens $\mathrm{R} 8$ reduces hepatic oxidative stress and enhances nutrient metabolism and immunity against Aeromonas hydrophila and Streptococcus agalactiae in zebrafish (Danio rerio). Fish Shellfish Immunol., v.86, p.410-9, 2019. DOI: https://doi.org/10.1016/j.fsi.2018.11.047

LIU, S.; WANG, S.; CAI, Y.; LI, E.; REN, Z.; WU, Y.; ZHOU, Y.. Beneficial effects of a host gut-derived probiotic, Bacillus pumilus, on the growth, non-specific immune response and disease resistance of juvenile golden pompano, Trachinotus ovatus. Aquaculture, v.514, 2019. DOI: https://doi.org/10.1016/j.aquaculture.2019.734446

LOPES, J. P.; PONTES, C. S.; ARAÚJO, A.; SANTOS NETO, M. A.. Fatores bióticos e abióticos que influenciam o desenvolvimento de Branconeta (CRUSTACEA: ANOSTRACA). Rev. Bras. Enga. Pesca, v.3, n.1, 2008.

LÓPEZ-NADAL, A.; IKEDA-OHTSUBO, W.; SIPKEMA, D.; PEGGS, D.; MCGURK, C.; FORLENZA, M.; ... BRUGMAN, S. Feed, Microbiota, and Gut Immunity: Using the Zebrafish Model to Understand Fish Health. Frontiers in Immunology, v.11, 2020. DOI: https://doi.org/10.3389/fimmu.2020.00114
LÓPEZ, V. K.; CASTRO, P. C.; VAL, A.. Digestive Enzymes of Eight Amazonian Teleosts With Different Feeding Habits. J. Fish Biol., v.74, n.7, p.1620-1628, 2009. DOI: https://doi.org/10.1111/j.1095-8649.2009.02196.x

LUCA, A. S.; REINKE, M. D.; CURVO, L. R. V.; ALENCAR, S. B. A.. Criação de peixes na Amazônia legal brasileira: a piscicultura no município de Juína- Mato Grosso, Brasil. Revista Contribuciones a las Ciencias Sociales, 2017.

MAGALHÃES, Y. A.; BATISTA, A. S. M.; FONTENELLE, R. O. S.; JULIÃO, M. S. S.; LOIOLOA, P. M. G.; MESQUITA, R. M.; AGUIAR, F. L. L.; OLIVEIRA, A. R.. Qualidade microbiológica e físico-química da água dos açudes urbanos utilizados na dessedentação animal in Sobral, Ceará. Revista da Universidade Vale do Rio Verde, v.12, n.2, p.141-148, 2014.

MAKORI, A. J.; ABUOM, P. O.; KAPIYO, R.. Effects of water physico-chemical parameters on tilapia (Oreochromis niloticus) growth in earthen ponds in Teso North SubCounty, Busia County. Fish Aquatic Sci, v.20, n.30, 2017. DOI: https://doi.org/10.1186/s41240-017-0075-7

MAMUN, M. A. A.; NASREN, S.; RATHORE, S. S.; SIDIQ, M. J.; DHARMAKAR, P.; ANJUSHA, K. V.. Assessment of Probiotic in Aquaculture: Functional Changes and Impact on Fish Gut. Microbiology Research Journal International, v.29, v.1, p.110, 2019. DOI: https://doi.org/10.9734/mrii/2019/v29i130156

MAKINO, L. C.; FAUSTINO, F.; PAES, M. C. F.; BERALDOMASSOLI, M. C.; CARDOZO, M. V.; SCHOCKEN-ITURRINO, R. P.; NAKAGHI, L. S. O.. Morfologia e quantificação da microbiota intestinal do curimbatá (Prochilodus lineatus) e do cascudo cinza (Pterygoplichthys anisitsi) cultivados em cativeiro. Arquivo Brasileiro de Medicina Veterinária e Zootecnia, v.64, n.4, p.916-926, 2012. DOI: https://doi.org/10.1590/S0102-09352012000400019

MARCON, L.; BAZZOLI, N.; HONOR, M. A.; ANJOS, B. L. Histological and Histometric Evaluation of the Liver in Astyanax Bimaculatus (Teleostei: Characidae), Exposed to Different Concentrations of na Organochlorine Insecticide. The Anatomical Record, v.298, p.1754-1764, 2015.

MARDONES, A.; GONZÁLEZ, M.; RIVAS-MANCILLA, C.; VEGA, R.; AUGSBURGER, A.; ENCINA, F.; LOS RÍOS, P..

Determination of acute toxicity of ammonium in juvenile Patagonian blenny (Eleginops maclovinus). Brazilian Journal of Biology, São Carlos, v.79, n.4, 2018. DOI: http://dx.doi.org/10.1590/1519-6984.186991

MARQUES, É. T.; CARDOSO, A. S.; OLIVEIRA, C. R.; ARRUDA, N.O.; GOMES, M. E. S.; SOBRAL, M. C. M.; CUNHA, M. C. C.. Avaliação preliminar dos impactos de efluente de piscicultura na qualidade da água in região do submédio do rio São Francisco. In: SIMPÓSIO DA BACIA HIDROGRÁFICA DO RIO SÃO FRANCISCO, 1. Anais. Juazeiro, 2016.

MARTOS-SITCHA, J. A.; MANCERA, J. M.; PRUNET, P.; MAGNONI, L. J.. Editorial: Welfare and Stressors in Fish: Challenges Facing Aquaculture. Frontiers in Physiology, v.11, 2020. DOI: https://doi.org/10.3389/fphys.2020.00162

MATIAS, F. A.. Sustentabilidade da aquicultura: crescimento $x$ desenvolvimento. Revista Panorama da Aquicultura, v.1, 2016. 
MATTHIENSEN, A.; GALVÃO, J.; A.; PINTO, J. S. S.. Off-flavour in peixes cultivados é, ainda, dificuldade para produção nacional. Visão Agrícola, n.11, 2012.

MELLO, H. J.; MORAES, R. E.; NIZA, I. G.; MORAES, F, R.; OZÓRIO, R. O. A.; SHIMADA, M. T.; ENGRACIA FILHO, J. R.; CLAUDIANO, G. S.. Efeitos benéficos de probióticos no intestino de juvenis de Tilápia-do-Nilo. Pesq. Vet. Bras., v.33, n.6, p.724-730, 2013.

MEURER, F.; HAYASHI, C.; BOSCOLO, W. R.; KAVATA, L. B.; LACERDA, C. H. F.. Nível de arraçoamento para alevinos de lambari-do-rabo-amarelo (Astyanax bimaculatus). R. Bras. Zootec., Viçosa, v.34, n.6, p.1835-1840, 2015.

MOHAMMADI, F.; MOUSAVI, S. M.; ZAKERI, M.; AHMADMORADI, E.. Effect of dietary probiotic, Saccharomyces cerevisiae on growth performance, survival rate and body biochemical composition of three spot cichlid (Cichlasoma trimaculatum). International Journal of the Bioflux Society, v.9, n.3, 2016.

MOHAPATRA, S.; CHAKRABORTY, T.; PRUSTY, A. K.; PANIPRASAD, K.; MOHANTA, K. N.. Beneficial Effects of Dietary Probiotics Mixture on Hemato-Immunology and Cell Apoptosis of Labeo rohita Fingerlings Reared at Higher Water Temperatures. PLoS ONE, v.9, n.6, 2014. DOI: http://dx.doi.org/10.1371/journal.pone.0100929

MOHAPATRA, S.; CHAKRABORTY, T.; KUMAR, V.; DEBOECK, G.; MOHANTA, K. N.. Aquaculture and stress management: a review of probiotic intervention. Journal of Animal Physiology and Animal Nutrition, v.97, n.3, p.405-430, 2013. DOI: http://dx.doi.org/2012.10.1111/j.14390396.2012.01301.x

MPURINO, J. L. P.; VIEIRA, F. N.; JATOBA, A. B.; SILVA, B. C.; JESUS, G. F. A.; SEIFFERT, W. Q.. Effect of dietary supplementation of inulin and W. cibaria on hematoimmunological parameters of hybrid surubim (Pseudoplatystoma sp). Aquac Nutr, v.18, n.1, p.73-80, 2012. DOI: https://doi.org/10.1111/j.1365-2095.2011.008 79.x

MOTA, V. C.; NILSENB, T. O.; GERWINSA, J.; GALLOC, M.; YTTEBORGD, E.; BAEVERFJORDA G.; KOLAREVICA, J.; SUMMERFELT, S. T.; TERJESENA, B. F.. The effects of carbon dioxide on growth performance, welfare, and health of Atlantic salmon post-smolt (Salmo salar) in recirculating aquaculture systems. Aquaculture, v.498, p.578-586, 2019. DOI: https://doi.org/10.1016/j.aquaculture.2018.08.075

MUKHERJEE, A.; DUTTA, D.; BANERJEE, S.; RINGO, E.; BREINES, E. M.; HAREIDE, E.. Potential probiotics from Indian major carp, Cirrhinus mrigala. Characterization, pathogen inhibitory activity, partial characterization of bacteriocin and production of coenzymes. Research in Veterinary Science, v.108, p.76-84, 2016.

NAKANDAKARE, I. B.; IWASHITA, M. K. P.; DIAS, D. C.; TACHIBANA, L.; RANZANI-PAIVA, M. J. T.; ROMAGOSA, E.. Incorporação de Probióticos na dieta para juvenis de tilápiasdo-nilo: parâmetros hematológicos, imunológicos e microbiológicos, Bol. Inst. Pesca, São Paulo, v.39, n.2, p.121135, 2013.

NASRUDDIN, N. S.; AZMAI, M. N. A.; ISMAIL, A.; SAAD, M. Z.;
DAUD, H. M.; ZULKIFLI, S. Z.. Histological features of the gastrointestinal tract of wild Indonesian shortfin eel, Anguilla bicolor bicolor (McClelland, 1844), Captured in peninsular Malaysia. Scientific World Journal, v.2014, p.1-8. DOI: https://doi.org/10.1155/2014/312670

NAVARRO, Z.. Ciência e agricultura. Cienc. Cult., São Paulo, v.69, n.4, p.26-28, 2017. DOI: http://dx.doi.org/10.21800/2317-66602017000400010

NGUYEN, T. L.; PARK, C.-I.; KIM, D.-H.. Melhor taxa de crescimento e resistência a doenças em solha de oliva, Paralichthys olivaceus, pelo probiótico Lactococcus lactis WFLU12 isolado de peixes marinhos selvagens. Aquaculture, v.471, p.113-120, 2017. DOI: https://doi.org/10.1016/j.aquaculture.2017.01.008

NOBILE, A. B.; FREITAS-SOUZA, D.; LIMA, F. P.; QUEIROZ, J.; BAYONA-PEREZ, I. L.; CARVALHO, E. D.; RAMOS, I. P.. Damming and seasonality as modulators of fish community structure in a small tributary. Ecol. Freshw. Fish., p.1-10, 2019. DOI: https://doi.org/10.1111/eff.12475

NWACHI, O. F.. Na overview of the importance of probiotics in aquaculture. Journal of Fhiseries an Aquatic Science, v.8, n.1, 2013

OPIYO, M. A.; JUMBE, J.; NGUGI, C. C.; CHARO-KARISA, H.. Dietary administration of probiotics modulates non-specific immunity and gut microbiota of Nile tilapia (Oreochromis niloticus) cultured in low input ponds. International journal of veterinary science and medicine, v.7, n.1, p.1-9, 2019. DOI: https://doi.org/10.1080/23144599.2019.1624299

ORNELAS-GARCÍA, P.; PAJARES, S.; SOSA-JIMÉNEZ, V.M.; RÉTAUX, S.; MIRANDA-GAMBOA, R. A.. Microbiome differences between river-dwelling and cave-adapted populations of the fish Astyanax mexicanus (De Filippi, 1853). Peer J., 2018. DOI: https://doi.org/10.7717/peerj.5906

PEDROZA FILHO, M. X.; RODRIGUES, A. P. O.; REZENDE, F. P. Dinâmica da produção de tambaqui e demais peixes redondos no Brasil. Embrapa Pesca e Aquicultura, Outras publicações técnicas (INFOTECA-E), 2016.

PEREIRA, S. L. A.. Agentes Patogênicos de Tambaquis Cultivados, Com Destaque Para Registros em Rio Preto da Eva. Documentos 127. EMBRAPA Amazônia Ocidental, 2016.

PERRY, W. B.; LINDSAY, E.; PAYNE, C. J.; BRODIE, C.; KAZLAUSKAITE, R.. The role of the gut microbiome in sustainable teleost aquaculture. Proceedings of the Royal Society B: Biological Sciences, v.287, n.1926, 2020. DOI: https://doi.org/10.1098/rspb.2020.0184

PRODANOV, C. C.; FREITAS, E. C.. Metodologia do trabalho científico: métodos e técnicas da pesquisa e do trabalho acadêmico. 2 ed. Novo Hamburgo: Feevale, 2013.

RAY, A. K.; RING $\varnothing$, E.. The Gastrointestinal Tract of Fish. Aquaculture Nutrition, p.1-13, 2014. DOI: https://doi.org/10.1002/9781118897263.ch1

ROBINSON, C. D.; KLEIN, H. S.; MURPHY, K. D.; PARTHASARATHY, R.; GUILLEMIN, K.; BOHANNAN, B. J. M.. PLoS Biol., v.16, 2018. DOI: 
https://doi.org/10.1371/journal.pbio.2006893

ROCHA, C. M. C.; RESENDE, E. K.; ROUTLEDGE, E. A. B.; LUNDSTEDT, L. M.. Avanços na pesquisa e no desenvolvimento da aquicultura brasileira. Pesq. Agropec. Bras., Brasília, v.48, n.8, p.4-6, 2013.

RODILES, A.; RAWLING, M. D.; PEGGS, D. L.; PEREIRA, G. V.; VOLLER, S.; YOMLA, R.; STANDEN, B. T.; BOWYER, P.; MERRIFIELD, D. L.. Applications for Finfish Aquaculture. Springer International Publishing. In: DI GIOIA, D. B.. Probiotics and Prebiotics in Animal Health and Food Safety. Springer, 2017.

SADO, R. Y.; SOUZA, F. C.; BEHR, E. R.; MOCHA, P. R. E.; BALDISSEROTTO, B.. Anatomy of Teleosts and elasmobranchs. In: BALDISSEROTO, B.; URBINATI, E. C.; CYRINO, J. E. P.. Biology and Physiology Freswater Neotropical Fish. London: Academic Press (Elsevier), 2020. p.21-47. DOI: https://doi.org/10.1016/b978-0-12-81 58722.00002-6

SAFARI, R.; ADEL, M.; LAZADO, C. C.; CAIPANG, C. M. A.; DADAR, M.. Host-derived probiotics Enterococcus casseliflavus improves resistance against Streptococcus iniae infection in rainbow trout (Oncorhynchus mykiss) via immunomodulation. Fish \& Shellfish Immunology, v.52, p.198-205, 2016. DOI: https://doi:10.1016/j.fsi.2016.03.020

SAYYAF-DEZFULIA, B.; MANERAB, M.; BOSIC, G.; MERELLAD, P.; DEPASQUALEE, J. A.; GIARIA, L.. Intestinal granular cells of a cartilaginous fish, thornback ray Raja clavata: Morphological characterization and expression of different molecule. Fish and Shellfish Immunology, v.75, p.172-180, 2018. DOI: http://dx.doi.org/10.1 016/j.fsi.2018.02.019

SOUZA, F. P. ; LIMA, E. C. S.; URREA-ROJAS, A. M.; SUPHORONSKI, S. A.; FACIMOTO, C. T.; BEZERRA JÚNIOR, J. S.; OPERA-BARRERO, N. M.. Effects of dietary supplementation with a microalga (Schizochytrium sp.) on the hemato-immunological, and intestinal histological parameters and gut microbiota of Nile tilapia in net cages. PLOS ONE, v.15, n.1, e0226977, 2020. DOI:

https://doi.org/10.1371/journal.pone.0226977

PARRIS, D. J.; MORGAN, M. M.; STEWART, F. J.. Feeding rapidly alters microbiome composition and gene transcription in the clownfish gut. Appl. Environ. Microbiol., v.85, 2019. DOI: https://doi.org/10.1128/AEM.02479-18

SAFRA, M. E. B.; LEMOS, J. G. A.; TOSCANO, M.; BOTAZZARI, N.; MENOLLI, K. A. P.. A utilização de probióticos e prebióticos in rações caninas e felinas - Dieta, cachorro, felinos, probiótico, prebiótico. Revista Nutritime, v.15, n.1, 2018.

SANTOS, M. P. N.; SEIXAS, S.; AGGIO, R. B. M.; HANAZAKI, N.; COSTA, M.; SCHIAVETTI, A.; DIAS, J. A.; AZEITEIRO, U. M.. A Pesca enquanto Atividade Humana: Pesca Artesanal e Sustentabilidade. Revista de Gestão Costeira Integrada, v.12, n.4, p.405-427, 2012.

SCHMIDT, V. T.; SMITH, K. F.; MELVIN, D. W.; AMARALZETTLER, L. A.. Community assembly of a euryhaline fish microbiome during salinity acclimation. Molecular Ecology, v.24, n.10, p.2537-2550, 2015. DOI:

https://doi.org/10.1111/mec.13177
SCHULTER, E. P.; VIEIRA FILHO, J. E. R.. Evolução da piscicultura no Brasil: diagnóstico e desenvolvimento da cadeia produtiva de tilápia. Brasília: IPEA, 2017.

SHRIVASTAVA, J.; SINHA, A. K.; CANNAERTS, S.; BLUST, R.; BOECK, G.. Temporal assessment of metabolic rate, ammonia dynamics and ion-status in common carp during fasting: a promising approach for optimizing fasting episode prior to fish transportation. Aquaculture, v.481, p.218-228, 2017. DOI: https://doi.org/10.1016/j.aquacultu re.2017.09.008

SILVA, N. J. R.. Dinâmicas de desenvolvimento da piscicultura e políticas públicas no Vale do Ribeira/SP e Alto Vale do Itajaí/SC. Tese (Doutorado em Aquicultura) Universidade Estadual Paulista "Julio de Mesquita Filho", Jaboticabal, 2005.

SILVA, W. L. M.. As políticas da administração pública para a aquicultura no estado das amazonas: avaliação dos aspectos ambientais, econômicos e sociais. Dissertação (Mestrado em Ciências Ambientais) - Universidade Federal do Amazonas, Humaitá, 2017.

SILVA, L. E. S.; GALÍCIO, G. S.. Alimentação de peixes in piscicultura intensiva. Enciclopédia Biosfera, Centro Científico Conhecer, Goiânia, v.8, n.15.

SILVEIRA, U. S.; LOGATO, P. V. R.; PONTES, E. C. P.. Fatores estressantes in peixes. Revista Eletrônica Nutritime, v.6, p.1000-1017, 2019.

SIPAÚBA-TAVARES, L. H.; LOURENÇO, E. M.; BRAGA, F. M. S. Water quality in six sequentially disposed fish ponds with continuous water flow. Acta Scientiarum. Biological Sciences, v.32, n.1, p.9-15, 2010.

SMALL, B. C.; HARDY, R. W.; TUCKER, C. S.. Modulation of intestinal microbiota in solea senegalensis fed low dietary Level of Ulva ohnoi. Frontiers in Microbiology, v.10, n.171, p.1-16, 2019. DOI: https://doi.org/10.2527/af.2016-0043

SOUTO, A. C.; LIMA, F. P.; GILDO, N. M.; VIDOTTOMAGNONI, A. P.. Dieta das espécies de peixes do reservatório e seus principais tributários. In: SILVA, R. J.. Integridade ambiental da represa de Jurumirim: ictiofauna e relações ecológicas. São Paulo: UNESP, 2016. p.95-113.

STAGAMAN, K.; BURNS, A.; GUILLEMIN, K.. The role of adaptive immunity as an ecological filter on the gut microbiota in zebrafish. ISME J., v.11, p.1630-1639, 2017. DOI: https://doi.org/10.1038/ismej.2017.28

STEPHENS, W. Z.; BURNS, A. R.; STAGAMAN, K.; WONG, S.; RAWLS, J. F.; GUILLEMIN, K.. The composition of the zebrafish intestinal microbial community varies across development. ISME J., v.10, p.644-54, 2016. DOI: https://doi.org/10.1038/ismej.2015.140

TALWAR, C.; NAGAR, S.; LAL, R.; NEGI, R. K.. Fish Gut Microbiome: Current Approaches and Future Perspectives. Indian Journal of Microbiology, v.58, n.4, 2018. DOI: https://doi.org/10.1007/s12088-018-0760-y

TANTIKITTI, C.; SANGPONG, W.; CHIAVAREESAJJA, S.. Effects of defatted soybean protein levels on growth performance 
and nitrogen and phosphorus excretion in Asian seabass (Lates calcarifer). Aquaculture, v.248, p.41-50, 2015.

TAPIA-PANIAGUA, S. T.; FUMANAL, M.; ANGUÍS, V.; FERNÁNDEZ-DÍAZ, C.; ALARCÓN, F. J.; MORIÑIGO, M. A.; BALEBONA, M. C.. Modulation of Intestinal Microbiota in Solea senegalensis Fed Low Dietary Level of Ulva ohnoi.

Frontiers in Microbiology, v.10, 2019. DOI: https://doi.org/10.3389/fmicb.2019.00171

TARNECKI, A. M.; WAFAPOOR, M.; PHILLIPS, R. N.; RHODY, N. R.. Benefits of a Bacillus probiotic to larval fish survival and transport stress resistance. Scientific Reports, v.9, v.1, 2019. DOI: https://doi.org/10.1038/s41598-019-39316-w

TEIXEIRA, A. S.. Alimentos e Alimentação dos Animais. Lavras: UFLA, 2001.

THAISS, C. A.; ZMORA, N.; LEVY, M.; ELINAV, E.. The microbiome and innate immunity. Nature, v.535, p.65-74, 2016. DOI: https://doi.org/10.1038/nature18847

TONI, M.; ANGIULLI, E.; MALAVASI, S.; ALLEVA, E.; CIONI, C.. Variation in Environmental Parameters in Research and Aquaculture: Effects on Behaviour, Physiology and Cell Biology of Teleost Fish. J. Aquac. Mar. Biol., v.5, n.6, p.00137, 2017. DOI:

https://doi.org/10.15406/jamb.2017.05.00137

TORRES, S. M.; PEREIRA, F. A. R.; SOUZA, C. C.; FERREIRA, M. B.. Análise da eficiência da produção da piscicultura na região de Dourados - MS. Revista Espacios, v.38, n.52, 2017.

SYLVAIN, F.-É.; HOLLAND; A.; AUDET-GILBERT, É.; VAL, A. L.; DEROME, N.. Amazon fish bacterial communities show structural convergence along widespread hydrochemical gradients. Molecular Ecology, v.28, n.15, p.3612-3626., 2019. DOI: https://doi.org/10.1111/mec.15184

VALENTIM, J. K.; BITTENCOURT, T. M.; RODRIGUES, R. F. M.; VIANA, C. H. R.; ALMEIDA, G. R.. Utilização de probióticos para aves tipo caipira Avicultura no Brasil, sistema alternativo, dieta para frangos, probióticos, desempenho nutricional. Nutritime, v.14, n.6, 2017.

VAN DOAN, H.; HOSEINIFAR, S. H.; DAWOOD, M. A. O.. Effects of Cordyceps militaris spent mushroom substrate and Lactobacillus plantarum on mucosal, serum immunology and growth performance of Nile tilapia (Oreochromis niloticus). Fish \& Shellfish Immunology, v.70, n.C, p.87-94, 2017. DOI: https://doi.org/10.1016/j.fsi.2017.09.002

VAN DOAN, H.; HOSEINIFAR, S. H.; KHANONGNUCH, C. KANPIENGJAI, A.; UNBAN, K.; VAN KIM, V.; SRICHAIYO, S.. Host-associated probiotics boosted mucosal and serum immunity, disease resistance and growth performance of Nile tilapia (Oreochromis niloticus). Aquaculture, v.491, p.94-100, 2018. DOI:

https://doi:10.1016/j.aquaculture.2018.03.019

VAN DOAN, H.; HOSEINIFAR, S. H.; RING $\varnothing$, E.; ESTEBAN, Á. M.; DADAR, M.; DAWOOD, M. A. O.; FAGGIO, C.. HostAssociated Probiotics: A Key Factor in Sustainable Aquaculture. Reviews in Fisheries Science \& Aquaculture, p.1-27, 2019. DOI:

https://doi.org/10.1080/23308249.2019.1643288
VEIGA, P. T. N.; OWATARI, M. S.; NUNES, A. L.; RODRIGUES, R. A.; KASAI, R. Y. D.; FERNANDES, C. E.; CAMPOS, C. M.. Short communication: Bacillus subtilis C-3102 improves biomass gain, innate defense, and intestinal absorption surface of native Brazilian hybrid Surubim (Pseudoplatystoma corruscans x P.reticulatum). Aquacult Int, v.28, p.1183-1193, 2020. DOI: https://doi.org/10.1007/s10499-020-00519-y

VIEIRA, B. B.; PEREIRA, E. L.. Potencial dos Probióticos para o uso na aquicultura. Revista da Universidade Vale do Rio Verde, Três Corações, v.14, n.2, p.1223-1241, 2016.

WANG, A. R.; RAN, C.; RING $\varnothing$, E.; ZHOU, Z. G.. Progress in fish gastrointestinal microbiota research. Reviews in Aquaculture, v.10, n.3, p.626-640, 2017. DOI: https://doi.org/10.1111/raq.12191

WANKA, K. M.; DAMERAU, T.; COSTAS, B.; KRUEGER, A. SCHULZ, C.; WUERTZ, S.. Isolation and characterization of native probiotics for fish farming. BMC Microbiol., v.18, n.119, 2018.

WANKA, K. M.; SCHULZ, C.; KLOAS, W.; WUERTZ, S. Administration of host-derived probiotics does not affect utilization of soybean meal enriched diets in juvenile turbot (Scophthalmus maximus). J. Appl. Ichthyol., v.35, p.10041015, 2019. DOI: https://doi.org/10.1111/jai.13929

WANJA, D. W.; MBUTHIA, P. G.; WARUIRU, R. M.; MWADIME, J. M.; BEBORA, L. C.; NYAGA, P. N.; NGOWI, H. A.. Fish Husbandry Practices and Water Quality in Central Kenya: Potential Risk Factors for Fish Mortality and Infectious Diseases. Veterinary Medicine International, p.110, 2020. DOI: https://doi.org/10.1155/2020/6839354

WU, Z.-Q.; JIANG, C.; LING, F.; WANG, G.-X. Effects of dietary supplementation of intestinal autochthonous bacteria on the innate immunity and disease resistance of grass carp (Ctenopharyngodon idellus). Aquaculture, v.438, p.105-114, 2015. DOI:

https://doi.org/10.1016/j.aquaculture,2014.12.041

XIANG, L.; SUN, T.-F.; MO, C.-H.; LI, Y.-W.; CAI, Q.-Y. LI, H.. Related environmental problems and research progresses of quaternary ammonium compounds (QACs). Huaxue Jinzhan, v.28, p.727-736, 2016. DOI: http://dx.doi.org/10.7536/PC151129

YANG, G.; JIAN, S. Q.; CAO, H.; WEN, C.; HU, B.; PENG, M.; PENG, L.; YUAN, J.. Lifeng Liange Changes in microbiota along the intestine of grass carp (Ctenopharyngodon idella): Community, interspecific interactions, and functions. Aquaculture, v.498, p.146-156, 2019. DOI: https://doi.org/10.1016/j.aquaculture.2018.08.062

ZACARDI, D. M.; LIMA, M. A. S.; NASCIMENTO, M. M.; ZANETTI, C. R. M.. Caracterização socioeconômica e produtiva da aquicultura desenvolvida in Santarém, Pará. Acta Fish, v.5 n.3, p.102-112, 2017

ZAINELDIN, A. I.; HEGAZI, S.; KOSHIO, S.; ISHIKAWA, M.; BAKR, A.; EL-KEREDY, A. M. S.; YUKUN, Z.. Bacillus subtilis as probiotic candidate for red sea bream: Growth performance, oxidative status, and immune response traits. Fish \& Shellfish Immunology, v.79, p.303-312, 2018. DOI: https://doi.org/10.1016/i.fsi.2018.05.035 
ZANG, L.; MA, Y.; HUANG, W.; LING, Y.; SUN, L.; WANG, X. WANG, H.. Dietary Lactobacillus plantarum ST-III alleviates the toxic effects of triclosan on zebrafish (Danio rerio) via gut microbiota modulation. Fish \& Shellfish Immunology, v.84, p.1157-1169, 2019. DOI:

https://doi.org/10.1016/j.fsi.2018.11.007

ZANIBONI FILHO, E.; PEDRON, J. S.; RIBOLLI J.. Opportunities and challenges for fish culture in Brazilian reservoirs: a review. Acta Limnologica Brasiliensia, v.30, 2018. DOI: https://doi.org/10.1590/S2179-975X117

ZHOU, Q.-C.; WANG, L.-G.; WANG, H.-L.; WANG, T.; ELMADA C.-Z.; XIE, F.-J.. Dietary vitamin E could improve growth performance, lipid peroxidation and non-specific imune responses for juvenile cobia (Rachycentron canadum). Aquaculture Nutrition, v.19, p.421-429, 2014

ZHOU, S.; SONG, D.; ZHOU, X.; MAO, X.; ZHOU, X.; WANG, S.; QIN, Q.. Characterization of Bacillus subtilis from gastrointestinal tract of hybrid Hulong grouper (Epinephelus fuscoguttatus $\times$ E. lanceolatus) and its effects as probiotic additives. Fish \& Shellfish Immunology, v.84, p.1115-1124, 2018. DOI: https://doi.org/10.1016/i.fsi.2018.10.058

ZORRIEHZAHRA, M. J.; DELSHAD, S. T.; ADEL, M.; TIWARI, R.; KARTHIK, K. DHAMA, K.; LAZADO, C. C.. Probiotics as beneficial microbes in aquaculture: an update on their multiple modes of action: a review. Veterinary Quarterly, v.36, n.4, p.228-241, 2016. DOI:

https://doi.org/10.1080/01652176.2016.1172132

A CBPC - Companhia Brasileira de Produção Científica (CNPJ: 11.221.422/0001-03) detém os direitos materiais desta publicação. Os direitos referem-se à publicação do trabalho em qualquer parte do mundo, incluindo os direitos às renovações, expansões e disseminações da contribuição, bem como outros direitos subsidiários. Todos os trabalhos publicados eletronicamente poderão posteriormente ser publicados em coletâneas impressas sob coordenação da Sustenere Publishing, da Companhia Brasileira de Produção Científica e seus parceiros autorizados. Os (as) autores (as) preservam os direitos autorais, mas não têm permissão para a publicação da contribuição em outro meio, impresso ou digital, em português ou em tradução. 